\title{
TLR4 Signaling Selectively and Directly Promotes CGRP Release from Vagal Afferents in the Mouse
}

\author{
Lin Jia, ${ }^{1}$ Syann Lee, ${ }^{1}$ Jessica A. Tierney, ${ }^{2}$ Joel K. Elmquist, ${ }^{1}{ }^{\circ}$ Michael D. Burton, ${ }^{2, *}$ and \\ (1)Laurent Gautron ${ }^{1, *}$
}

\section{https://doi.org/10.1523/ENEURO.0254-20.2020}

${ }^{1}$ Center for Hypothalamic Research and Department of Internal Medicine, The University of Texas Southwestern Medical Center, Dallas, TX 75390 and ${ }^{2}$ Neuroimmunology and Behavior Laboratory, Department of Neuroscience, School of Behavioral and Brain Sciences, and Center for Advanced Pain Studies, University of Texas at Dallas, Richardson, TX 75081

\section{Visual Abstract}

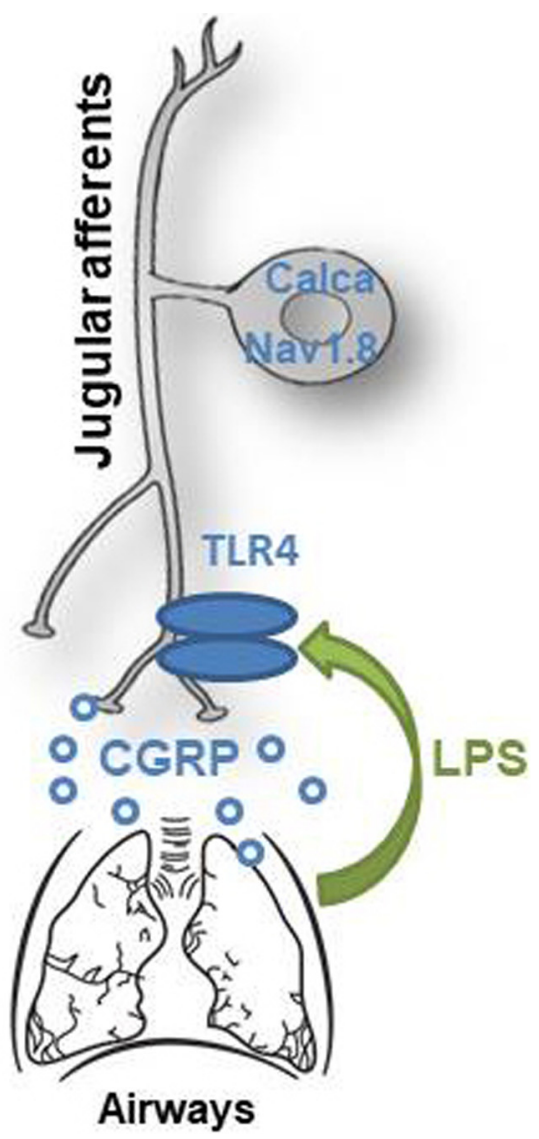

There has been a long-standing debate regarding the role of peripheral afferents in mediating rapid-onset anorexia among other responses elicited by peripheral inflammatory insults. Thus, the current study assessed the sufficiency of peripheral afferents expressing toll-like receptor 4 (TLR4) to the initiation of the anorexia caused by peripheral bacterial lipopolysaccharide (LPS). We generated a TIr4 null (TIr4 ${ }^{\text {LoxTB}}$ ) mouse in which TIr4 expression is globally disrupted by a loxP-flanked transcription blocking (TB) cassette. This novel mouse model allowed us to restore the endogenous TLR4 expression in specific cell types. Using Zp3-Cre and $\mathrm{Na}_{v} 1.8-\mathrm{Cre}$ 


\section{Significance Statement}

Using a new transgenic mouse model, our data establish that toll-like receptor 4 (TLR4) is both sufficient and required for the release of calcitonin gene-related peptide (CGRP) from a subset of vagal afferents. This finding may be relevant to the understanding of how bacterial infections modulate nerves.

mice, we produced mice that express TLR4 in all cells (TIr4 ${ }^{\text {LoxTB }} \times$ Zp3-Cre) and in peripheral afferents (TIr4 ${ }^{\text {LoxTB }} \times \mathrm{Na}_{\mathrm{v}}$ 1.8-Cre), respectively. We validated the TIr4 ${ }^{\text {LoxTB }}$ mice, which were phenotypically identical to previously reported global TLR4 knock-out mice. Contrary to our expectations, the administration of LPS did not cause rapid-onset anorexia in mice with $\mathrm{Na}_{v} 1.8$-restricted TLR4. The later result prompted us to identify TIr4-expressing vagal afferents using in situ hybridization (ISH). In vivo, we found that TIr4 mRNA was primarily enriched in vagal $\mathrm{Na}_{v} 1.8$ afferents located in the jugular ganglion that co-expressed calcitonin gene-related peptide (CGRP). In vitro, the application of LPS to cultured $\mathrm{Na}_{\mathrm{v}} 1.8$-restricted TLR4 afferents was sufficient to stimulate the release of CGRP. In summary, we demonstrated using a new mouse model that vagally-expressed TLR4 is selectively involved in stimulating the release of CGRP but not in causing anorexia.

Key words: Cre-loxP; innate immunity; neuropeptide; vagus nerve

\section{Introduction}

Toll-like receptor 4 (TLR4) is the main membrane receptor for lipopolysaccharides (LPS), which are endotoxins derived from the outer membrane of Gram-negative bacteria (Poltorak et al., 1998a,b, 2000; Chow et al., 1999). Hence, the immunologic effects of LPS are blunted in TLR4-deficient mice (Hoshino et al., 1999). That said, other membrane proteins, including the myeloid differentiation factor 2 (Park et al., 2009) and TRP channels (Meseguer et al., 2014; Alpizar et al., 2017) also contribute to LPS signaling. Upon exposure to LPS, anorexia ensues (Kent et al., 1992; Porter et al., 1998a) as the direct result of the actions of proinflammatory molecules on the CNS (Layé et al., 1994; Grossberg et al., 2010; Daniel et al.,

Received June 11, 2020; accepted December 3, 2020; First published December 14, 2020.

The authors declare no competing financial interests.

Author contributions: S.L., J.K.E., M.D.B., and L.G. designed research; L.J., J.A.T., and L.G. performed research; J.A.T. contributed unpublished reagents/ analytic tools; L.J., S.L., M.B., and L.G. analyzed data; L.J., M.D.B., and L.G. wrote the paper.

L.J. was supported by the National Institutes of Health Grant K01AA024809. L.G. was supported by the Irwin \& Irma Grossman Research Fund for Type I Diabetes (University of Texas Southwestern). M.D.B. was supported by the National Institutes of Health Grant K22NS096030, The American Pain Society Future Leaders grant, and the Rita Allen Foundation. The microcopy facility is supported by the National Institutes of Health Award 1 S10 OD021685-01A1 to Kate Luby-Phelps.

${ }^{*}$ M.D.B. and L.G. contributed equally to this work.

Acknowledgements: We thank Abhijit Bugde from The University of Texas Southwestern Live Cell Imaging Core Facility for his help with confocal microscopy, Dr. John Wood (University College London) for kindly providing us with Nav1.8-Cre mice, and Claudia Vianna, Arely Tijano, Rebekah Brown, and Newaz Ahmed for their technical assistance (The University of Texas Southwestern).

Correspondence should be addressed to Laurent Gautron at laurent. gautron@UTSouthwestern.edu or Michael D. Burton at michael.burton@ UTDallas.edu.

https://doi.org/10.1523/ENEURO.0254-20.2020 Copyright $\odot 2021$ Jia et al.

This is an open-access article distributed under the terms of the Creative Commons Attribution 4.0 International license, which permits unrestricted use, distribution and reproduction in any medium provided that the original work is properly attributed.
2016; Essner et al., 2017). While the anorexic effects of LPS occur within minutes (Liu et al., 2016), LPS does not cross the blood-brain barrier (Banks and Robinson, 2010), suggesting that a peripheral neural mechanism involving vagal afferents may contribute to LPS-induced anorexia. This is because the peripheral endings of vagal afferents are outside the blood-brain barrier and directly accessible to bacterial products located in vagally-innervated tissues. Experiments conducted in deafferented animals are in agreement with this view (Bluthé et al., 1994; Bret-Dibat et al., 1995; Layé et al., 1995; Konsman et al., 2000). However, it was never clear whether LPS could directly act on peripheral neurons until TLR4 was found to be expressed in peripheral afferents, including those in the vagus nerve (Hua et al., 1996; Hosoi et al., 2005; Ochoa-Cortes et al., 2010; de Lartigue et al., 2011; Diogenes et al., 2011; Due et al., 2012; Kunda et al., 2014; Helley et al., 2015; Li et al., 2015; Boonen et al., 2018). Moreover, the ability of isolated sensory neurons to directly and rapidly respond to LPS has been reported in different species using electrophysiology and calcium signaling (Riley et al., 2013; Meseguer et al., 2014). The in vivo administration of LPS has also been reported to produce changes in the neuropeptide expression and firing rate of vagal afferents (Huang and Lai, 2003; Liu et al., 2007). Thus, it is plausible that this mechanism allows peripheral sensory neurons to detect infections in a rapid manner (Clatworthy and Grose, 1999; Chiu et al., 2013; Soldano et al., 2016). Finally, it must be noted that within the brain, TLR4 is expressed in endothelial and glial cells, but not in neurons (Laflamme and Rivest, 2001; Chakravarty and Herkenham, 2005; Kigerl et al., 2007). The latter observation suggests that peripheral afferents are likely the only neurons in the body able to sense changing levels of TLR4 activators in a direct manner.

Other findings contradict the view that TLR4 is present and functional in vagal afferents. Another RNA sequencing study of vagal afferents failed to detect any vagal afferents with significant TIr4 mRNA expression (Wang et al., 2017). This is without mentioning that several 
laboratories have demonstrated that interrupting vagal afferents does not prevent the host of physiological responses to peripheral LPS, including anorexia (Bret-Dibat et al., 1997; Schwartz et al., 1997; Hansen et al., 2000; Martin et al., 2000; Wieczorek et al., 2005). Considering that vagal afferents are exquisitely sensitive to a wide range of proinflammatory molecules (Ek et al., 1998; Yu et al., 2005; Feldman-Goriachnik et al., 2015), it remains possible that the aforementioned cellular and physiological effects of LPS are not directly mediated by TLR4 signaling in vagal afferents themselves. Given the above uncertainties in the field, the current study aimed to reassess the sufficiency of vagal afferents TLR4 to select LPSinduced responses using a newly generated transgenic mouse model.

\section{Materials and Methods}

\section{Mice}

Mice were all housed in a barrier facility in a light-controlled and temperature-controlled environment [zeitgeber $(Z T) 0=6$ A.M.] with ad libitum access to standard chow, unless specified otherwise (Harlan Teklad TD.2016 Global). Experimental mice were males, whereas females were only used for breeding purposes. Single housing was required during the course of food intake studies. Otherwise, animals were group housed at all time. All the procedures in this study were approved by our Institutional Animal Care and Use Committees and in accordance with the Society's Policies on the Use of Animals and Humans in Neuroscience Research.

\section{Wild-type (WT) C57BI/6 mice}

A total of six male mice, between six and eight weeks of age, on a pure $\mathrm{C} 57 \mathrm{Bl} / 6$ background were used for chromogenic in situ hybridization (ISH) experiments. These mice were obtained from our Animal Resource Center.

\section{$\mathrm{Na}_{V}$ 1.8-Cre ${ }^{\text {ChR2-YFP }}$ reporter mice}

We also generated and genotyped $\mathrm{Na}_{\mathrm{v}} 1.8-\mathrm{Cre}-\mathrm{ChR} 2-$ YFP mice carrying one Cre allele and one ChR2-YFP allele. A total of four males between six and eight weeks of age, were used for chromogenic ISH combined with GFP immunostaining experiments.

\section{Generation of novel Cre-reactivated TLR4-null mice (T/r4 $\left.{ }^{\text {LoxTB}}\right)$}

To generate TIr4 ${ }^{\text {LoxTB }}$ mice, BAC clones containing the murine Tlr4 gene derived from the 129/Sv strain were obtained from the Sanger Institute. The BAC DNA clone number bMQ58F22 was electroporated into EL350 bacteria. First, the loxP sequences present in the BAC backbone were removed by homologous recombination as previously described (Lee et al., 2001). Then the validated loxP-flanked transcription blocking (TB) sequences (Berglund et al., 2012) were amplified by PCR using primers 5'-GCCTCATTA GAAGTGGAATGATAGAAACTCACAGAAATTAATGGGTTC CCAAGATCATGGGTACCCGCGCCTAGTCGACTTCGAA TAACTT-3' and 5'-TGTTAAAAAGAATATCGCAAGAGGAAT CCATGGAGCCATGTTAACTCTCCATTCTTCCTGGGTGGCGGCCGCTTAGTITA-3'. The amplicon was then inserted between exons 2 and 3 of the Tlr4 gene by homologous recombination in EL350 cells (Lee et al., 2001). Kanamycin-resistant clones were selected and recombination was verified by PCR using the following primers: 5'CTGGACAAACAGTGGCTGGA-3' and 5'-GTCATAGATGC ATGCCAGATACA-3'. Next, the Amp resistance sequence in the EL350 clones with correctly targeted Tlr4 BAC DNA (LoxTB-TIr4) was replaced with a Zeocin resistance cassette. pZErO-1 vector (Invitrogen) was used to amplify the Zeocin resistance sequence by PCR, and the amplicon was inserted by homologous recombination. Zeocin resistant clones were selected and recombination was verified by PCR. Following this, the pGEM-T easy vector (Promega) was used as a template to generate an amplicon containing two TIr4 homology arms using primers: 5'-CCATTCAAACTGGAACATAGC CACCTAATTATITGTCTCTTGTTAGCCAAGTGAAATAGCgcggccgcCCAACGCGTTGGATGCATAGC-3' and 5'GTGTGGGTGAAGGTAAGAGTAGCTGTATGCATTACATAGATGTATGAAATTGTCAAAGAGCGGTATITCTCCTTACGCATC-3'. The TIr4 ${ }^{\text {LoxTB }}$ gene was inserted into the pGEM-T easy vector through homologous recombination and positive clones were verified by PCR using primers: 5'-ACCTGATGCGGTGTGAAATAC-3' and 5'AGGAAACAGCTATGACCATGA-3'. Sequencing of the amplicons was performed and enzymatic digestions were conducted to confirm on-target homologous recombination, the sequences of the loxP-flanked TB cassette, and TIr4 native sequences. The targeting vector, which consisted of the LoxTB-TIr4 gene flanked by 3.2$\mathrm{kb}$ (left) and 5.2-kb (right) Tlr4 homology arms was prepared using a commercially available kit (QIAGEN), linearized by Pvul enzymatic digestion and electroporated into 129/SvJ ES cells by the transgenic core facility at The University of Texas Southwestern Medical Center. To identify the recombinant clones, genomic DNA was extracted from ES cells as previously described (Berglund et al., 2012) and used for long PCR assays to discriminate between ES clones hosting WT and loxP-modified TIr4 allele. Correct targeting was further confirmed by a custom multiplex TaqMan quantitative PCR (qPCR) assay. Briefly, extracted DNA was used as template (5-100 ng). Melanocortin 4 receptor (MC4R) was used as an endogenous reference (ID Mm00457483_s1, FAM dye-labeled probe; Applied Biosystems). Custom primers (5'-TCCTA ACAGAAAGTGGAAACTTGAG-3' and 5'-AGGAATCCA TGGAGCCATGTTA-3') and VIC dye-labeled probe (5'CCCAAGATCATGCAGGAAGAAT-3') from Biosearch Technologies were multiplexed with the MC4R assay. DNA-based qPCRs were conducted on an Applied Biosystems PRISM 7900HT sequence detection system. Correctly targeted recombinant ES cells were injected into blastocysts of $\mathrm{C} 57 \mathrm{BI} / 6$ mice. Chimeric male mice (F0) were crossed to $\mathrm{C} 57 \mathrm{BI} / 6$ female mice and their pups (F1) were screened for germ line transmission by PCR using the same strategy as for genotyping. F1 pups bearing the Cre-reactivatable TIr4-null allele (TIr ${ }^{\text {LoxTB }}$ ) were then crossed with zona pellucida 3 (Zp3)-Cre transgenic mice (stock \#003651 C57BL/6$\mathrm{Tg}(\mathrm{Zp3}$-cre)93Knw/J) to restore endogenous TLR4 expression in all tissues (TIr $4^{\text {LoxTB }} \times$ Zp3-Cre). Mice 
carrying a WT and/or Cre-mediated recombination allele (TIr4 ${ }^{\text {LoxTB }}$ X Zp3-Cre) were genotyped by primer pairs P1 (5'-CTGACTGGTGTGAAGTGGAATATC-3') and P3 (5'GTCATAGATGCATGCCAGATACA-3'). Primers P2 (5'CTGGACAAACAGTGGCTGGA-3') and P3 were used to screen the TIr $4^{\text {LoxTB }}$ allele. Globally reactivated mice were used for validation studies and feeding tests. The group size is indicated in figure legends.

TIr4 ${ }^{\text {LOXTB }} \times \mathrm{Na}_{v} 1.8$-Cre mice

F1 pups bearing the Cre-reactivated TIr $4^{\text {LoxTB }}$ allele were then crossed with $\mathrm{Na}_{v} 1.8$-Cre mice to produce mice with endogenous TLR4 reactivation only in $\mathrm{Na}_{\mathrm{v}} 1.8$ neurons (TIr4 ${ }^{\text {LoxTB }} \times \mathrm{Na}_{\mathrm{v}} 1.8$-Cre). These mice are referred to as $\mathrm{Na}_{v} 1.8$-restricted TIr4 mice. For all studies, breeding was set up to obtain the following groups: control, TIr4 ${ }^{\text {LoxTB }}$, and $\mathrm{Na}_{\mathrm{v}} 1.8$-restricted TIr4 mice. Controls consisted of mice expressing one copy of the $\mathrm{Na}_{\mathrm{v}} 1.8-\mathrm{Cre}$ allele. TIr $4^{\text {LoxTB }}$ mice expressed two copies of the TIr $4^{\text {LoxTB }}$ allele without Cre. $\mathrm{Na}_{\mathrm{v}}$ 1.8-restricted $\mathrm{TI} 4$ mice expressed two copies of the TIr ${ }^{\text {LoxTB }}$ allele and one Cre allele. To validate our ISH probe, we also compared the ganglia from two TIr4 ${ }^{\text {LoxTB }}$ mice to that of two globally reactivated mice (TIr4 ${ }^{\text {LoxTB }} \times$ Zp3-Cre). Mice were maintained on a mixed (C57BI/6 and 129) genetic background. Male mice entered the experiments at 8-16 weeks of age and were used for feeding and calcitonin gene-related peptide (CGRP) studies. The group size is indicated in figure legends.

\section{LPS preparation and dosage}

For animal and culture experiments, we kept $1 \mathrm{mg} / \mathrm{ml}$ aliquots of LPS solution (Sigma L2880 Escherichia coli 055:B5) in sterile pyrogen-free $0.9 \%$ saline (Sigma) at $-20^{\circ} \mathrm{C}$. When needed, LPS was diluted 100 times in sterile saline for animal studies or in sterile media for culture studies. In all our feeding studies, LPS was administered at a single dose of $100 \mu \mathrm{g} / \mathrm{kg}$ of body weight (intraperitoneal). This moderate dose is sufficient to induce rapid and transient anorexia in the mouse (Bret-Dibat and Dantzer, 2000; Lawrence et al., 2012; Liu et al., 2016). A dose of $2 \mathrm{mg} / \mathrm{kg}$ (intraperitoneal) was used to stimulate Nfkbia expression in the nodose ganglion. This dosage was chosen based on a prior study demonstrating LPS-induced gene expression changes in the nodose ganglion (Huang and Lai, 2003). A dose of $500 \mathrm{ng} / \mathrm{ml}$ of LPS was used for nodose organotypic culture studies (Marrone et al., 2017).

\section{LPS-induced inflammatory response in mice}

WT, TIr4 $4^{\text {LoxTB }}$, and TIr4 ${ }^{\text {LoxTB }} \times$ Zp3-Cre mice (710 weeks old) were treated with LPS ( 1 or $0.5 \mathrm{mg} / \mathrm{kg}$ body weight) by intraperitoneal injection. Blood was collected $1.5 \mathrm{~h}$ after injection by tail bleeding. Plasma TNF $\alpha$ concentrations were determined using the MILLIPLEX MAP Mouse Cytokine/Chemokine panel (Millipore).

\section{Genomic DNA isolation}

Genomic DNA was isolated from tails of six-week-old mice using REDExtract-N-Amp Tissue PCR kit (Sigma) following the manufacturer's instructions.

\section{Feeding studies}

Individually-housed control, TIr4 deficient, and reactivated mice were fasted overnight. At $\sim 9$ A.M., fasted mice were weighed and immediately treated with either LPS or sterile saline. At the same time, mice were refed with chow. An experimenter continuously recorded the feeding behavior of each mouse over $60 \mathrm{~min}$ following treatment. At the end of the 60 -min period, food pellets and body weight were measured. Data were used to calculate the total amount of time spent eating in seconds.

\section{LPS-induced gene expression studies by qPCR}

Mice were fasted overnight. The next morning, body weights were measured to determine the injection volume of saline or LPS. Then, saline or LPS was administered at the single dosage of $2 \mathrm{mg} / \mathrm{kg}$, intraperitoneally. One hour postinjection, mice received an overdose of chloral hydrate $(500 \mathrm{mg} / \mathrm{kg}$, i.p.) and their nodose-jugular ganglia were rapidly removed and frozen in liquid nitrogen. Total RNAs were extracted using RNA Stat60 (Teltest) according to the manufacturer's instructions. RNA concentration and quality were determined by NanoDrop 1000 Spectrophotometer (Thermo Scientific). Complementary DNA was synthesized using the High Capacity cDNA kit and was performed at $25^{\circ}$ $\mathrm{C}$ for $10 \mathrm{~min}, 37^{\circ} \mathrm{C}$ for $120 \mathrm{~min}$, and $85^{\circ} \mathrm{C}$ for $5 \mathrm{~min}$ (Applied Biosystems). Primers for Tlr4 (ID: Mm0445274_m1), Nfkbia (ID: Mm00477798_m1), and 18s (ID: Hs99999901_s1) were purchased from Applied Biosystems. The mRNA contents were normalized to $18 \mathrm{~s}$ mRNA levels. qPCR was performed in an ABI Prism 7900HT sequence detection system (Applied Biosystems) using TaqMan Master Mix (Applied Biosystems) and $10 \mathrm{ng}$ of synthesized cDNA. Samples were run in triplicates. The relative amounts of all mRNAs were calculated using the $\Delta \Delta C T$ assay.

\section{ISH, microscopy, and digital images analysis}

Mice received an overdose of chloral hydrate $(500 \mathrm{mg} /$ $\mathrm{kg}$, i.p.), before being transcardiacally perfused with $10 \%$ formalin (Sigma). The nodose-jugular ganglionic mass was rapidly dissected and kept in formalin for an additional $24 \mathrm{~h}$ at $4^{\circ} \mathrm{C}$. Fixed ganglia were next incubated overnight in a solution of $20 \%$ sucrose in PBS $(\mathrm{pH} 7.4)$ at $4^{\circ} \mathrm{C}$ before being frozen on a bed of dry ice. Series of $14-\mu \mathrm{m}$ sections were collected on SuperFrost slides using a cryostat. Tissue was stored at $-80^{\circ} \mathrm{C}$ for less than a couple of weeks. The tissue was processed for ISH following the manufacturer's instructions (Advanced Cell Diagnostics) with only minor adjustments to the pretreatment. Specifically, slides were baked for $\sim 30$ min at $60^{\circ} \mathrm{C}$ before starting the pretreatment. In addition, the target retrieval solution was heated up to $87^{\circ} \mathrm{C}$ instead of $99^{\circ} \mathrm{C}$. Table 1 summarizes the probes, chromogenic labels, and reagents used in the current study. Tissue sections labeled for TIr4 alone or TIr4 combined with Calca (CGRP precursor gene) were counterstained with a hematoxylin solution (GHS132 Sigma). Tissue sections from $\mathrm{Na}_{v} 1.8-\mathrm{Cre}^{\mathrm{ChR} 2-\mathrm{YFP}}$ mice were not counterstained, but further processed for GFP immunohistochemistry. Briefly, after several PBS washes, the sections were incubated overnight at room temperature in a chicken anti-GFP primary antiserum (Aves Laboratory; GFP- 
Table 1: List of reagents used for ISH

\begin{tabular}{|c|c|c|c|c|c|c|}
\hline \multicolumn{7}{|c|}{ ISH RNAscope reagents from ACD } \\
\hline $\begin{array}{l}\text { Gene style } \\
\text { name(s) }\end{array}$ & $\begin{array}{l}\text { Accession } \\
\text { number }\end{array}$ & $\begin{array}{l}\text { Probe } \\
\text { region }\end{array}$ & $\begin{array}{l}\text { Catalog } \\
\text { number } \\
\text { channel }\end{array}$ & $\begin{array}{l}\text { Chromogenic } \\
\text { labels }\end{array}$ & Pretreatment & Kits \\
\hline Calca-C1 & NM_007587.2 & 44-995 & 417961-C1 & $\begin{array}{c}\text { HRP-based } \\
\text { Green }\end{array}$ & $\begin{array}{l}\text { RNAscope Hydrogen Peroxide } \\
\text { RNAscope Target Retrieval } \\
\text { RNAscope Protease III }\end{array}$ & RNAscope2.0 2-plex \\
\hline TIr4-C2 & NM_021297.2 & 2404-3775 & $316801-C 2$ & $\begin{array}{l}\text { AP-based } \\
\text { Fast Red }\end{array}$ & & \\
\hline
\end{tabular}

10120; RRID:AB_10000240; 1:1000) in 3\% normal donkey serum with $0.25 \%$ Triton X-100 in PBS. On the following day, sections were washed and incubated for $1 \mathrm{~h}$ in a biotinylated anti-chicken secondary antibody (catalog \#703065155; Jackson ImmunoResearch; 1:1000), followed by Streptavidin Alexa Fluor 488 (Invitrogen, \#S11223; 1:1000). All our slides were coverslipped with EcoMount mounting medium (Biocare Medical, LLC EM897L).

Bright-field images were captured using a Zeiss microscope (Imager $\mathrm{ZI}$ ) attached to a digital camera (Axiocam). A camera lucida attached to the microscope was also used to draw tissue sections. Drawings were digitalized and exported to Adobe Illustrator Artwork 15.1. The Zeiss microscope (Imager ZI) was also used for manual counts of the ISH signals for cell profiles positive for TIr4/H\&E as well as TIr4/Calca. Cell profiles were counted on digital images by an experimenter unaware of our experimental design. Fluorescent digital images were all acquired with the $20 \times$ objective of a Zeiss microscope (Imager ZI) or the $63 \times$ objective of a Leica TCS SP5 confocal microscope (The University of Texas Southwestern Live Cell Imaging Core). Scanning parameters were adjusted appropriately to improve the signal/ background. We collected Z-stacks separated by $\sim 0.35-0.45 \mu \mathrm{m}$ in a $512 \times 512$-pixel format. NIH ImageJ software was used to generate our final TIFF images with combined Z stacks. Adobe Photoshop CS2 software was used to combine digital images into plates with annotations. The contrast and brightness of digital images were uniformly adjusted. Neuronal versus non-neuronal profiles were usually easily identifiable by the size, shape and intensity of the counterstaining of their nuclei. Our counts should be considered estimates rather than absolute counts. Cells that were considered doubly labeled included profiles with accumulation of TIr4 mRNA (at least one red dot per profile) within the boundaries of one Calca-positive profile. In addition, the circumference of each identified cell profile was assessed using the measurement tools in ImageJ. Images acquired by confocal microscopy were further evaluated for doubly labeled cells using plot of fluorescence intensities. Briefly, we manually traced a line across identified cell profiles using the Image J software (NIH, Fiji version). Plot profiles of gray values were generated for each color channel (overlapping red and green). Representative plot profiles were included in our figures. Cells with colocalized fluorescence displayed overlapping red and green plots of fluorescence across the line profile. Cells without staining or minimal colocalization displayed a flat plot profile in at least one channel. Colocalization data were expressed as the mean percentage of identified cell profiles \pm SEM, and the absolute numbers of counted profiles were included in the figures.

\section{Organotypic nodose ganglion and CGRP assays}

Our protocol was based on previous literature (Gavini et al., 2018). In particular, we chose to culture ganglia for 5-7 $d$ to give the samples time to rebound from the injury caused by the acute dissection. Male mice (five to eight weeks) were deeply anesthetized with isoflurane before being decapitated and the nodose/jugular ganglia were quickly removed and stored in chilled HBSS (Invitrogen) on ice. The isolated ganglia were placed on a $30 \mathrm{~mm}, 0.4 \mu \mathrm{m}$ pore size, hydrophilic Millicell culture insert (Millipore Sigma; catalog \#PICM03050) and maintained on the insert in DMEM F-12 GlutaMax media (Invitrogen) supplemented with $20 \%$ heat-inactivated horse serum (Invitrogen, Life Technologies), and $1 \times$ penicillin streptomycin (Invitrogen). Cultures were maintained for 5-7 $d$ with media changes every other day. After an overnight incubation in low serum (2.0\%), cultures were stimulated with $500 \mathrm{ng} / \mathrm{ml}$ LPS or vehicle for $24 \mathrm{~h}$ before supernatant was collected. Supernatants were centrifuged to remove debris and loaded to a CGRP ELISA kit (Cayman Chemical; catalog \#589001) and the protocol ran according to manufacturer's instructions.

\section{Statistical analysis}

All of the quantitative data are expressed as the mean value \pm SEM. The numbers of mice per group are indicated in each figure. Statistical analysis was performed using GraphPad Prism software, version 6.07. As indicated in the legends, the data were analyzed using Student's unpaired $t$ test, one-way ANOVA or two-way ANOVA, followed by the post hoc test recommended by the software; $p<0.05$ was considered statistically significant. Lower case letters were used to indicate groups found to be significantly different by the post hoc analysis. We also followed the journal's recommendations in terms of data representations and estimation statistics ( $\mathrm{Ho}$ et 

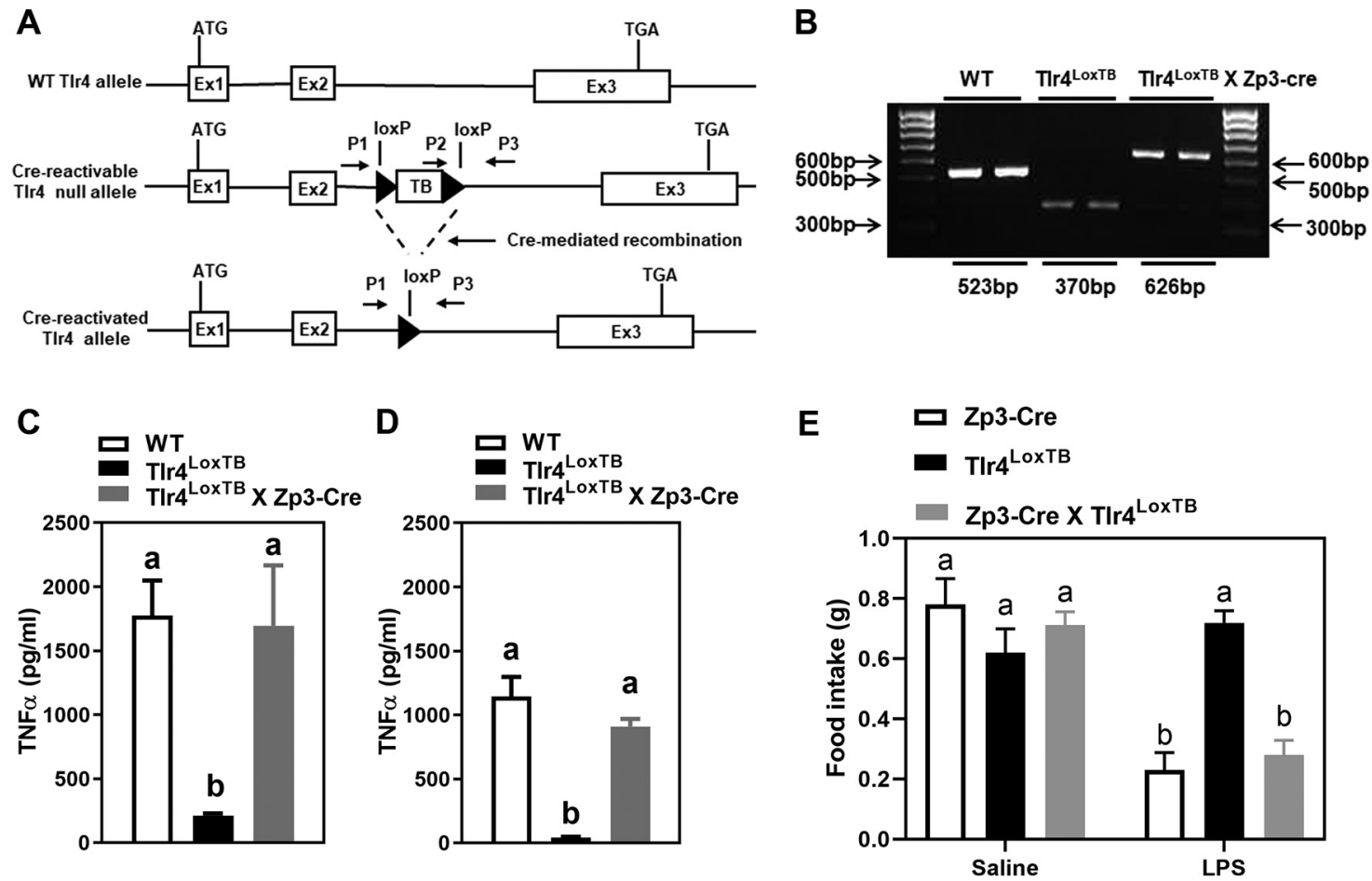

Figure 1. $\boldsymbol{A}, \mathrm{A}$ loxP-flanked transcription-blocking cassette was inserted between exons 2 and 3 of the TIr 4 gene to generate mice lacking TLR4. $\boldsymbol{B}$, Genotyping analysis of tail genomic DNA from WT, TIr $4^{\text {LoxTB }}$, and TIr $4^{\text {LoxTB }} \times$ Zp3-Cre mice. $\boldsymbol{C}, \boldsymbol{D}$, Plasma TNF $\alpha$ levels were measured in WT, TIr4 ${ }^{\text {LoxTB }}$ and TIr4 ${ }^{\text {LoxTB }} \times$ Zp3-Cre mice $(n=3-5) 1.5 \mathrm{~h}$ after intraperitoneally injection of LPS with the concentration of either $1 \mathrm{mg} / \mathrm{kg} \mathrm{BW}(\boldsymbol{C})$ or $0.5 \mathrm{mg} / \mathrm{kg}$ BW $(\boldsymbol{D})$. In $\boldsymbol{C}$, data were analyzed using one-way ANOVA for genotype $(p=0.0013)$, followed by Dunnett's test (WT vs TIr4 $\left.{ }^{\text {LoxTB }} p=0.0017\right)$. In $\boldsymbol{D}$, data were analyzed using one-way ANOVA for genotype $(p=0.0004)$, followed by Dunnett's test (WT vs TIr4 $\left.{ }^{\text {LoxTB }} p=0.0003\right)$. For cytokines, letters denote significant differences between columns with $p<0.05$, compared with corresponding TIr4 ${ }^{\text {LoxTB }}$ mice. $\boldsymbol{E}$, Graphs of 1 -h cumulative food intake in response to saline or LPS (100 $\mu \mathrm{g} / \mathrm{kg}$, i.p.) in control ZP3Cre (white), TIr4 ${ }^{\text {LoxTB }}$ (black), and Zp3-Cre-reactivated mice (gray). Groups consisted of $n=5$. Data are expressed as mean \pm SEM and were analyzed using two-way ANOVA for genotype $(p=0.0116)$, treatment $(p=0.0002)$, and interaction $(p=0.001)$, followed by Sidak's post hoc test. For each genotype, letters denote significant differences between columns with $p<0.05$, compared with corresponding saline-treated mice. Estimation statistics was calculated in LPS-treated mice. Estimation statistics are included in Extended Data Figure 1-1.

al., 2019). Estimation statistics are included in the legends of our main figures or Extended Data.

\section{Results}

\section{Validation of a novel reactivable TLR4 mouse model}

We designed and generated a novel TIr4 null (TIr4 $\left.{ }^{\text {LoxTB }}\right)$ mice whose Tlr4 expression is globally disrupted by a loxP-flanked TB cassette (LoxTB) that was inserted into the coding region of the Tlr4 gene (Fig. 1A). Crossing TIr4 ${ }^{\text {loxTB }}$ mice with Zp3-Cre mice produced mice in which expression of endogenous TIr4 was globally reactivated in all cells (Fig. 1A,B). As a result, the LPS-induced inflammatory response in these mice was identical to WT mice (Fig. 1C,D). Specifically, the administration of LPS produced a not significantly different increase in circulating TNF- $\alpha$ in WT and reactivated animals. However, TIr $4{ }^{\text {LoxTB }}$ mice (without Cre) behaved like global TLR4 knock-out mice and failed to respond to LPS (Fig. 1C,D). In a separate cohort, we tested the anorectic effects of a small dose of LPS (Fig. 1E). As anticipated, LPS suppressed food intake in Zp3-Cre mice, but not in TIr4 ${ }^{\text {LoxTB }}$ mice (without Cre). The anorectic effect of LPS (100 $\mu \mathrm{g} / \mathrm{kg}$, i.p.) was fully restored in mice with TIr4 reactivated in all cells that normally express it (Fig. 1E). This is because the expression of Tlr4 remains driven by its endogenous promoter. These studies demonstrate the validity of our reactivable model.

\section{TIr4-expressing vagal afferents do not initiate LPS- induced anorexia}

To test for functional TLR4 signaling in vagal afferents in vivo, we used the previously described $\mathrm{Na}_{v} 1.8$-Cre line (Stirling et al., 2005) to generate cohorts of mice that endogenously express TIr4 only in $\mathrm{Na}_{v} 1.8$ neurons. By qPCR, we show that TIr4 mRNA expression in the nodose-jugular ganglion was 15-fold higher in control mice than in TIr4 ${ }^{\text {LoxTB }}$ mice (without Cre; Fig. $2 A$ ). In $\mathrm{Na}_{v} 1$.8-restricted TIr4 animals, TIr4 expression in the nodose-jugular ganglion was $\sim 8$-fold higher than in TIr ${ }^{\text {LoxTB }}$ mice (Fig. 2A). TIr4 was selectively re-expressed in $\mathrm{Na}_{\mathrm{v}} 1.8$ neurons, but not other TIr4-expressing cell types. For example, TIr4 was not reactivated in the liver, a tissue with high endogenous expression of TIr4, but without $\mathrm{Na}_{\mathrm{v}} 1.8-\mathrm{Cre}$ cells (Fig. 2B). Lastly, the administration of LPS (2 mg/kg, 

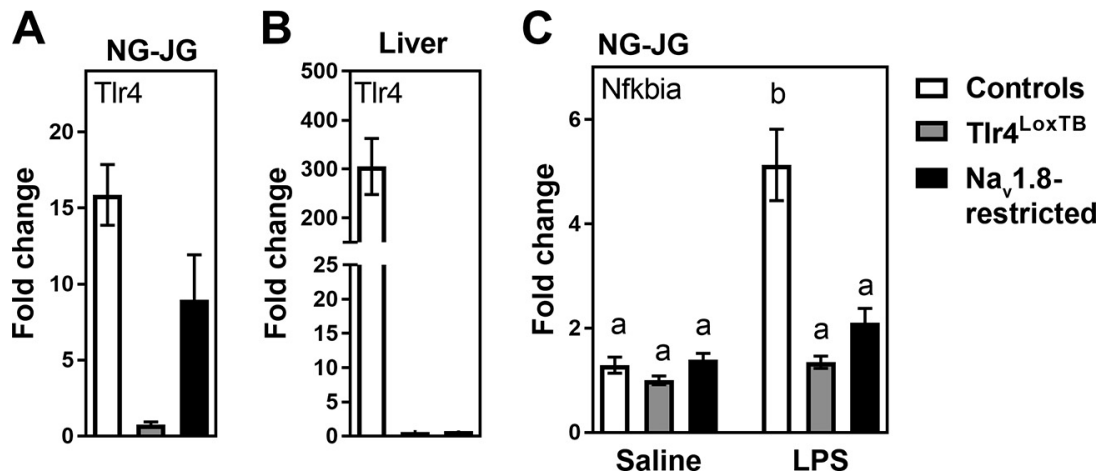

Figure 2. A, TIr4 mRNA expression in the nodose-jugular ganglionic mass of control, TIr4 ${ }^{\text {LoxTB }}$, and TIr4 ${ }^{\text {LoxTB }}$ crossed with Na 1.8 Cre mice ( $\mathrm{Na}_{\mathrm{v}}$ 1.8-restricted TLR4). Our GPCR demonstrated the re-expression of TIr4 in vagal afferents of reactivated animals. Groups consisted of $n=8-15$ mice. B, Restoration of TIr4 expression was not observed in the liver of reactivated mice, demonstrating the specificity of the Cre-reactivated allele. Groups consisted of $n=3-7$ mice. $\boldsymbol{C}$, Expression of Nfkbia mRNA in saline-treated and LPS-treated mice (2 mg/kg, i.p.) of each respective genotype. Groups consisted of $n=4-7$ mice. Data were all obtained by qPCR, and $18 \mathrm{~S}$ was used as a control gene. Data were analyzed using two-way ANOVA (treatment and genotype factors) followed by Sidak's post hoc test. Letters denote significant differences between columns with $p<0.05$. NG-JG: nodose-jugular ganglia; Nfkbia, NF $\kappa$ B inhibitor $\alpha$. Estimation statistics are included in Extended Data Figure 2-1.

i.p.) stimulated the expression of Nfkbia, a well-known TLR4 target gene (Quan et al., 1997), in the nodose-jugular ganglion of control animals (Fig. 2C). As anticipated, LPS did not elicit a transcriptional response in TIr4 LoxTB mice (Fig. 2C). LPS also failed to significantly increase Nfkbia expression in the ganglia of $\mathrm{Na}_{v} 1.8$-restricted TIr4 mice (Fig. 2C). This result is consistent with the view that TLR ligands and cytokines are generally poor inducers of the NF- $\kappa$ B pathway in neurons compared with other cell types (Listwak et al., 2013). Overall, our data established the successful re-expression of TIr4 in vagal afferents.

Early LPS-induced anorexia was investigated in control $\mathrm{Na}_{v} 1.8-\mathrm{Cre}$ mice with intact TIr4 expression. As anticipated, they showed rapid anorexia, starting $\sim 15$ min following LPS injection (Fig. 3A). The total amount of food that LPS-treated mice ate over $1 \mathrm{~h}$ was also significantly reduced (Fig. 3B). Weight gain was significantly reduced in LPS-treated mice (Fig. $3 C$ ). In contrast, LPS did not elicit anorexia or weight loss in mice that completely lacked TLR4 expression (Fig. 3D-F). In mice expressing TLR4 only in $\mathrm{Na}_{v} 1.8$ cells, LPS similarly failed to trigger anorexia or weight loss (Fig. 3G,H). We concluded that TLR4-bearing vagal $\mathrm{Na}_{\mathrm{v}} 1.8$ neurons do not contribute to the anorectic and cachectic actions of LPS at this particular dose and time point.

\section{TLR4 is selectively enriched in CGRP-positive afferents}

Although TIr4 mRNA has previously been described in the nodose ganglion (Hosoi et al., 2005), little information is available regarding its exact cellular distribution. Chromogenic ISH allowed us to detect the signal for the TIr4 transcript as a red precipitate (FastRed) visible under brightfield and fluorescent illuminations. The majority of the cellular profiles in the nodose and jugular ganglia was TIr4-negative or contained very few TIr4 signals (Fig. 4A$D$ ). Diffuse and weak TIr4 signals were seen in both neurons and non-neuronal cells in the nodose-jugular ganglia and the vagal trunk itself. However, a subset of cells resembling neurons contained moderate to high levels of TIr4 signals (Fig. $4 A-D$ ). Notably, neurons with high expression levels were not uniformly distributed but were concentrated in the jugular ganglion and the rostral pole of the nodose ganglion (Fig. 4A-D). The caudal nodose ganglion itself, which contains a large population of vagal neurons including gastrointestinal afferents, was largely devoid of TIr4-positive neurons. Based on our estimates, $<12 \%$ of vagal afferents located in the rostral nodose ganglion proper contained moderate to high levels of TIr4 signals (Fig. 4D). Considering that the boundary between the nodose and jugular-petrosal ganglia is ambiguous, many TIr4-positive neurons observed in the nodose ganglion may have been part of the jugular ganglion. Indeed, over $50 \%(n=3)$ of vagal afferents in the jugular ganglion were TIr4-positive and close to $25 \%(n=3)$ of them contained moderate to high levels of TIr4.

Our next studies sought to confirm the neuronal identity of TIr4-expressing cells. Specifically, $\mathrm{Na}_{\mathrm{v}} 1.8-\mathrm{Cre}^{\mathrm{ChR} 2-\mathrm{YFP}}$ was used to identify the cell bodies of vagal $\mathrm{Na}_{v} 1.8$ neurons. Chromogenic ISH was combined with GFP immunohistochemistry to visualize neurons co-expressing $\mathrm{Na}_{\mathrm{v}} 1.8$ and TIr4 (Fig. 5A-F). When combined with the detection of ChR2-labeled cells, it became evident that TIr4 mRNA was expressed by $\mathrm{Na}_{\mathrm{v}} 1.8$ neurons (Fig. $5 D, E$ ). In the nodose-jugular ganglia, $\sim 84 \% \quad(n=4)$ of Tlr4-expressing cells were also $\mathrm{Na}_{v} 1.8$-positive. Conversely, $\sim 9 \%(n=4)$ of $\mathrm{Na}_{\mathrm{v}} 1.8$-positive neurons expressed Tlr4. The jugular ganglion and rostral nodose ganglion are known to contain vagal afferents producing CGRP (Helke and Niederer, 1990; Mazzone and Undem, 2016). Therefore, we next performed double chromogenic ISH to simultaneously detect TIr4 and either Calca (CGRP precursor gene) or CGRP peptide. As anticipated, both TIr4 and Calca-expressing neurons were the most abundant in the jugular ganglion and the most rostral portion of the nodose ganglion (Fig. $6 A-D$ ). TIr4 mRNA signals often accumulated in Calca-expressing neurons (Fig. $6 B, C$ ), with an estimated 

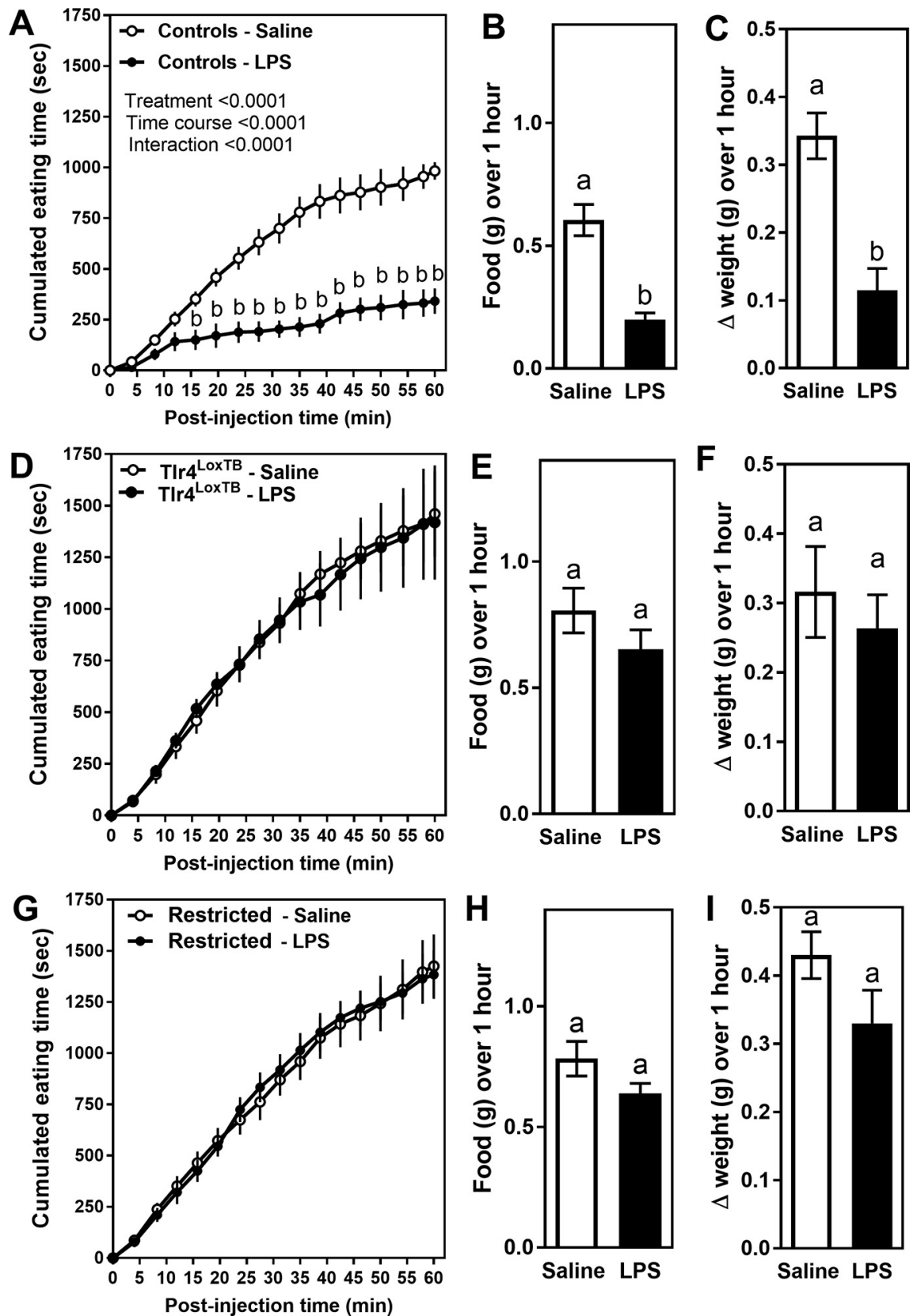

Figure 3. $\boldsymbol{A}, \boldsymbol{D}, \mathbf{G}$, Graphs of the cumulative food intake in response to saline (white) or LPS (black; $100 \mu \mathrm{g} / \mathrm{kg}$, i.p.) in control, Tlr4 ${ }^{\text {LoxTB }}$, and $\mathrm{Na}_{\mathrm{v}}$ 1.8-restricted TLR4 littermates. Groups consisted of $n=5-8$ mice. Data were analyzed using two-way ANOVA (time and treatment) separately for each genotype, followed by Sidak's post hoc test. The small letter b indicates points that are different from the saline-treated group. $\boldsymbol{B}, \boldsymbol{E}, \boldsymbol{H}$, Graph representing food intake or body weight change $(\boldsymbol{C}, \boldsymbol{F}, \boldsymbol{I})$ over the hour following LPS or saline treatment. Data were analyzed using Student's unpaired $t$ test. Small letters indicate significant differences between columns. Data are all expressed as the mean values \pm SEM over a period of 60 min. Estimation statistics are included in Extended Data Figure 3-1.

$40 \%(n=4)$ of Tlr4-expressing neurons also being Calcapositive (Fig. 6E). In summary, our anatomic data established that TIr4 was predominantly, but not exclusively, expressed by a subset of vagal afferents producing Calca, which are known to be mainly airways and facial somatosensory and nociceptive afferents (Helke and Niederer, 1990; Mazzone and Undem, 2016).

CGRP is an immunomodulatory peptide released from peripheral afferents during bacterial infections (Lai et al., 2017). Thus, we tested whether TLR4 signaling is sufficient and/or required for the release of CGRP from cultured vagal afferents. As anticipated, the application of LPS robustly raised CGRP release (Fig. $7 A, B$ ). In TIr4 ${ }^{\text {LoxTB }}$ mice, no significant changes in CGRP release were noticed following LPS. In the ganglia of $\mathrm{Na}_{\mathrm{v}} 1.8$-restricted TIr4 mice, the application of LPS raised CGRP release to the same degree as in the ganglia of control mice (Fig. $7 A, B)$. These data demonstrated that TLR4 signaling in vagal afferents directly mediates CGRP release on LPS exposure. Of note, the application of LPS did not alter the 

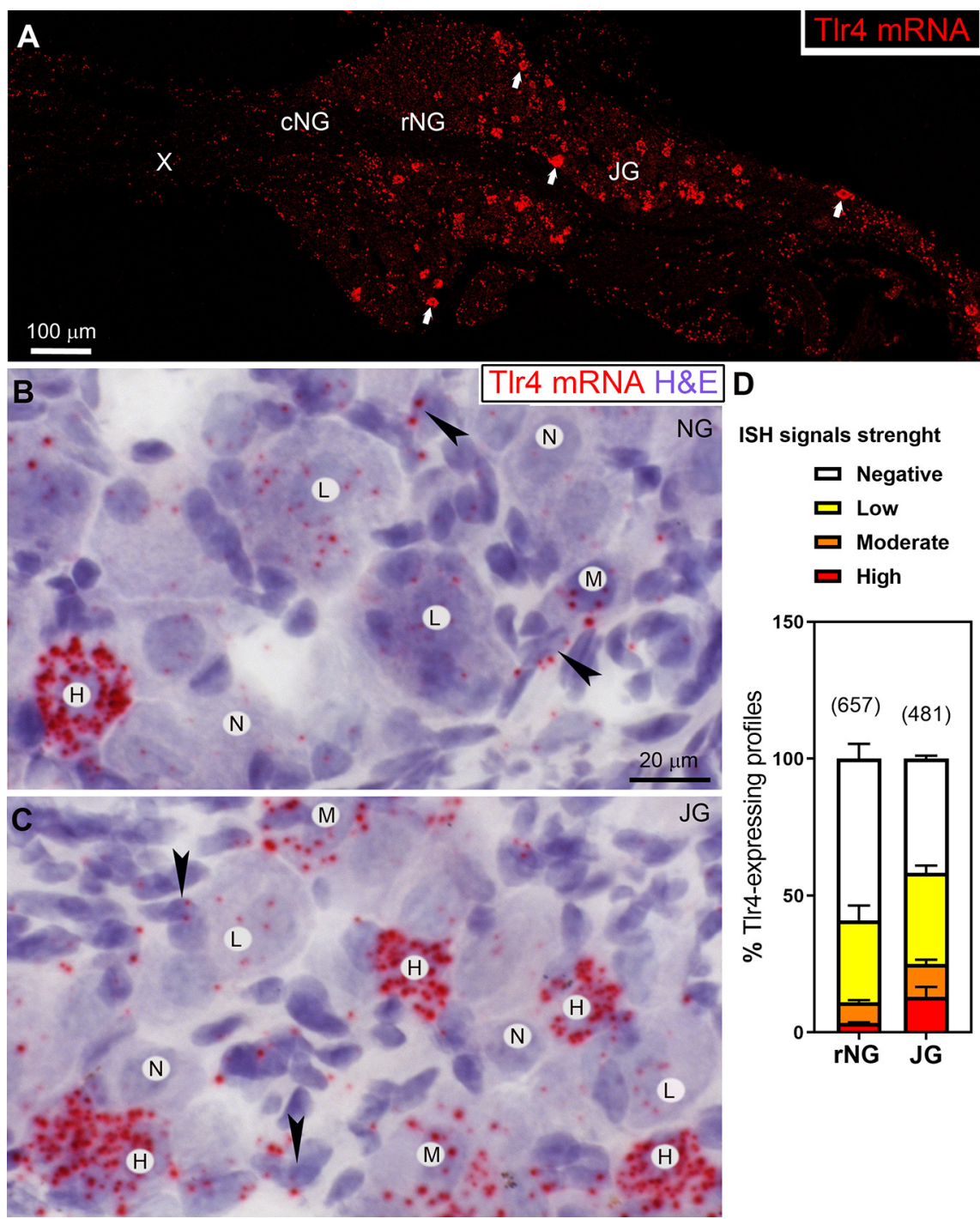

Figure 4. $\boldsymbol{A}-\boldsymbol{D}$, Chromogenic ISH for TIr4 mRNA (red) in the nodose and jugular ganglia of C57BI6/J mice. Using fluorescent illumination, scattered positive cells resembling neurons are observed mostly in the jugular portion of the ganglionic complex (white arrows). Under bright-field illumination, representative neuronal profiles were labeled as expressing Tlr4 signals at high (H), medium $(\mathrm{M})$, or low levels (L). Cells with no signals were also apparent $(\mathrm{N})$. Black arrows indicate putative non-neuronal cells surrounding neuronal profiles. Tissues were counterstained with hematoxylin (purple) to facilitate the identification of cellular profiles. The scale bars in $\boldsymbol{B}$ applies to $\boldsymbol{C}$. $\boldsymbol{D}$, Graph showing the percentage of neuronal profiles with different ISH signal strengths for TIr4. Data are expressed as the mean percentage \pm maximal values of Tlr4-expressing neurons in the nodose and jugular ganglia. The total number of counted profiles is indicated above each bar graph. The Extended Data Figure 4-1 includes a control of specificity for the TIr4 probe. c, caudal; $\mathrm{H}$, high intensity signal; HS, hematoxylin stain; $\mathrm{M}$, medium intensity signal; N, no visible signal; cNG, caudal nodose ganglion; rNG, rostral nodose ganglion; JG, jugular ganglion; L, low intensity signal; r, rostral.

transcription of TIr4 and Calca in sensory ganglia cultured for $5 \mathrm{~d}$ (see Extended Data Figure 7-1).

\section{Discussion}

\section{Novel tools for the study of TLR4}

LPS is a potent inducer of proinflammatory molecules, a number of which share the same cellular targets and intracellular signaling pathways as TLR4 (Miyamoto and Verma, 1995; Muta et al., 2002; Skelly et al., 2013). Combined with the redundancy of cells expressing TLR4 throughout the body (Poltorak et al., 1998a; Lin et al., 2000; Laflamme and Rivest, 2001; Liu et al., 2002), this has made it particularly difficult to tease apart the cellular and molecular determinants of TLR4 actions. Here, we developed and validated a novel mouse model to manipulate TLR4 expression in a cell type-specific manner within the context of intact animals. In the current study, we used this model to investigate the role played by peripheral afferents in LPS-induced anorexia. In theory, this approach can be used to test TLR4 signaling in any genetically-targeted cells provided that a Cre line is available. It has also been difficult to study TLR4 actions because of the lack of validated anti-TLR4 antibodies. While radioisotopic ISH has been used to detect TIr4-expressing cells in the CNS (Laflamme and Rivest, 2001; Chakravarty 


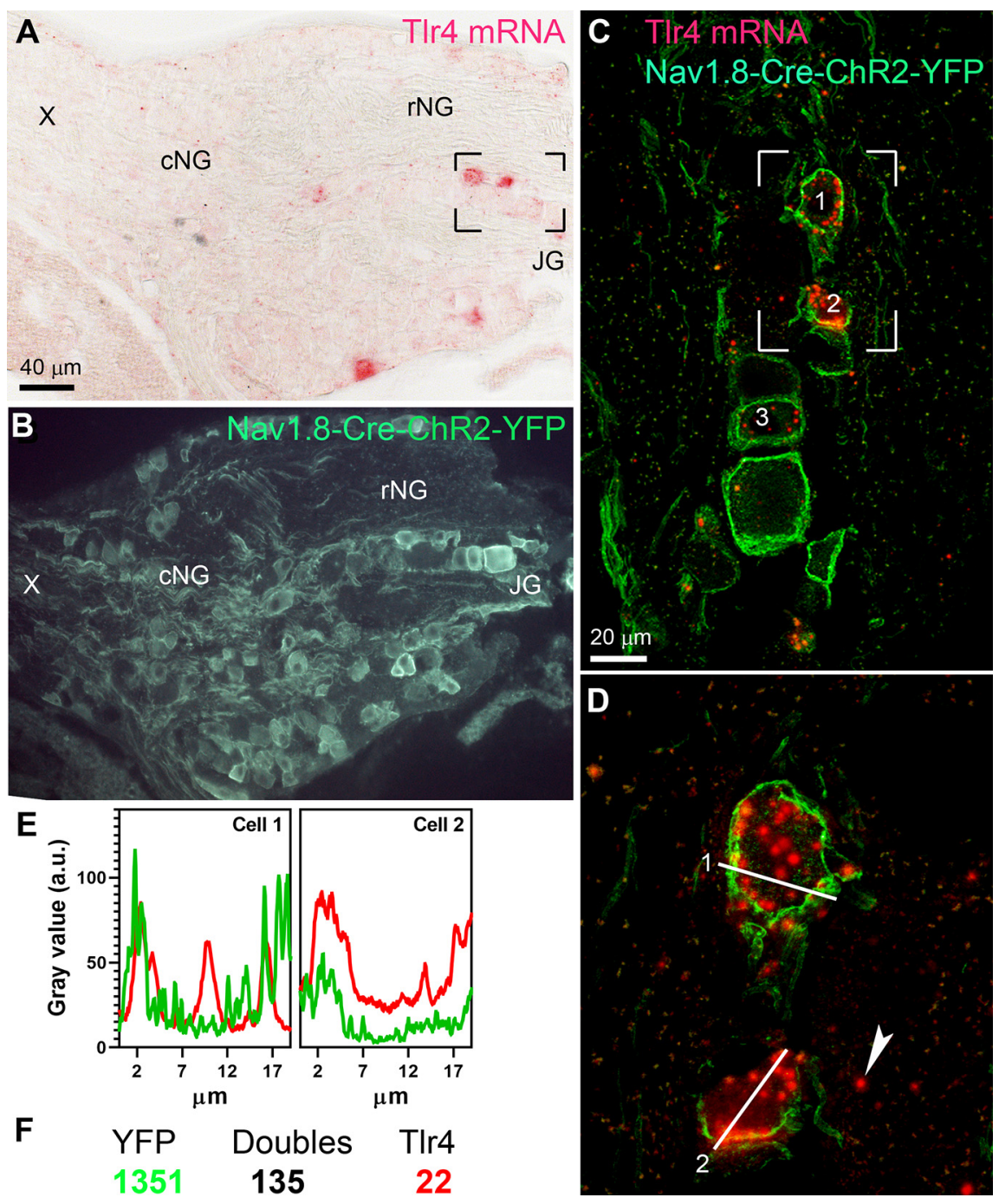

Figure 5. $\boldsymbol{A}, \boldsymbol{B}$, Chromogenic ISH for Tlr4 mRNA (red) in the rostral nodose ganglion of the Na $1.8-\mathrm{Cre}^{\mathrm{ChR} 2-\mathrm{YFP}}$ mouse. Immunolabeling for GFP (green) was used to label the cell bodies of $\mathrm{Na}_{v} 1.8$ neurons. $\boldsymbol{C}, \boldsymbol{D}$, At higher magnification (digital z-stack acquired by confocal microscopy), three large cells profiles with high intensity Tlr4 signals can be seen. The white arrowhead indicates scattered TIr4 signal interpreted as a putative non-neuronal cell. E. Plot profiles of the distribution across two cells represented in $\boldsymbol{D}$. The red and green lines correspond to the fluorescence intensity for TIr4 and YFP, respectively. Notably, Tlr4 signals strongly accumulated within the boundary of ChR2-YFP-labeled neurons. $\boldsymbol{F}$, Absolute numbers of counted cell profiles. From these data, it was concluded that TIr4 was primarily co-expressed by $\mathrm{Na}_{\mathrm{v}} 1.8$ neurons. cNG, caudal nodose ganglion; rNG, rostral nodose ganglion; JG, jugular ganglion; X, vagus nerve trunk.

and Herkenham, 2005), the present study has refined these techniques to specifically analyze TIr4 gene expression in vagal afferents. In particular, we used a highly sensitive ISH procedure called RNAscope (Advanced Cell Diagnostic; Wang et al., 2014; Grabinski et al., 2015). The latter technique allowed us to detect TIr4 mRNA with virtually no background. It also allowed us to easily detect Tlr4 in combination with other transcripts or GFP.

\section{Role of vagal afferents during inflammatory anorexia}

It is likely that peripheral afferents can rapidly convey information to the brain relevant to a potentially lethal threat, such as a Gram-negative bacterial infection. This phenomenon might possibly exist throughout the animal kingdom because sensory neurons in Aplysia sea slugs have been reported to be sensitive to bacterial LPS (Clatworthy and Grose, 1999). In rodents, numerous studies have suggested the ability of both vagal and spinal sensory neurons to respond to a broad range of inflammatory stimuli (Goehler et al., 1997; Ek et al., 1998; Ross et al., 2003; Eijkelkamp et al., 2010; La and Gebhart, 2011; Chiu et al., 2013). Prior studies have established that rodents with bilateral subdiaphragmatic surgical vagotomy showed diminished anorexia in response to LPS (Bret-Dibat et al., 1995; Sergeev and Akmaev, 2000). However, despite all of the evidence implicating peripheral afferents in sensing LPS, the requirement of vagal afferents in mediating LPS-induced anorexia has been difficult to demonstrate. For instance, other studies have 

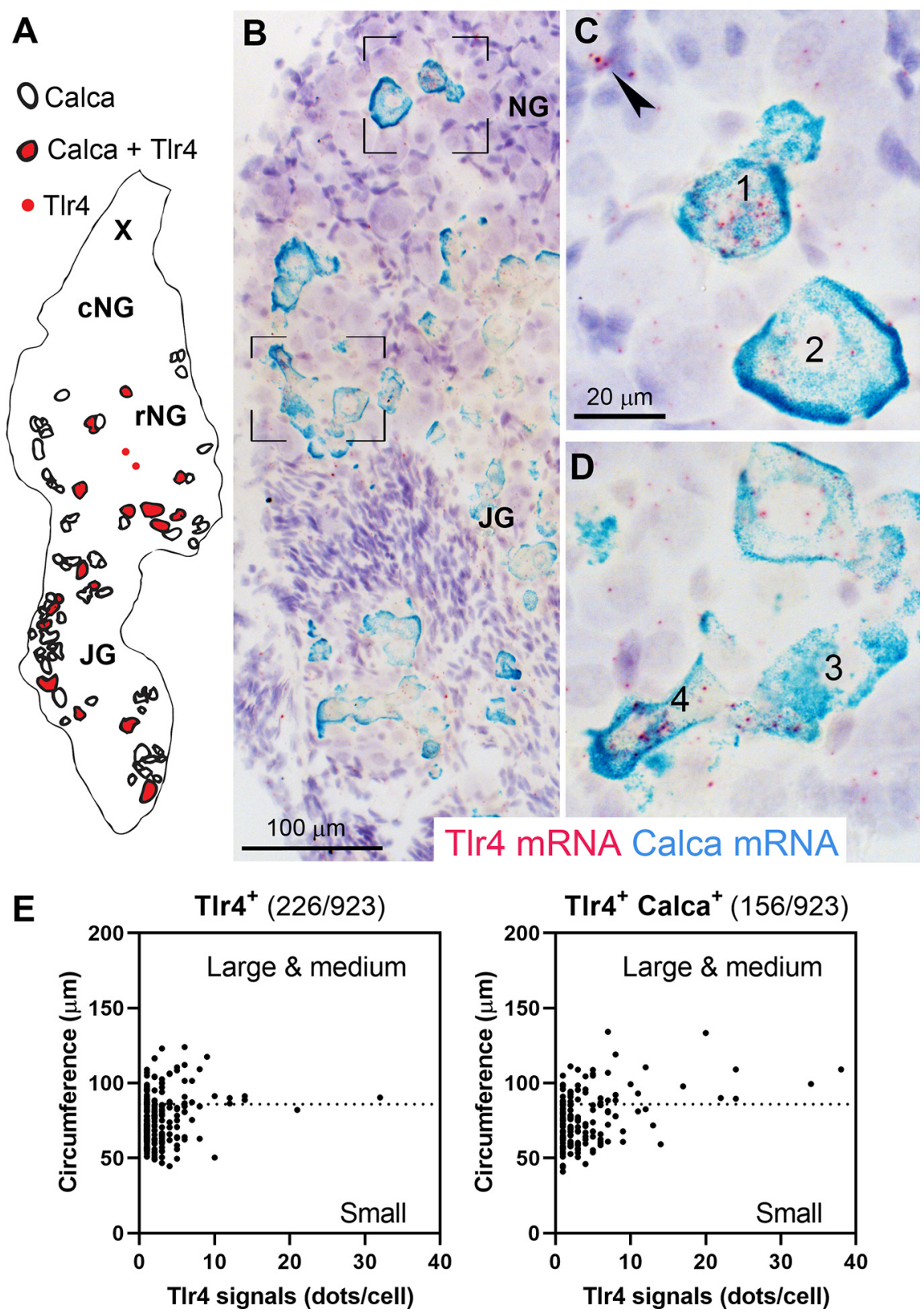

Figure 6. A, Camera lucida drawing of one vagal ganglionic complex processed for double chromogenic ISH for Tlr4 and Calca mRNAs. Each symbol represents one individual neuronal profile identified as positive for TIr4 (red dots), Calca (open circles), or both signals (circles filled with red). Note that both TIr4-positive and Calca-positive cells preferentially accumulated in the rostral pole of the ganglionic mass. $\boldsymbol{B}-\boldsymbol{D}$, Representative bright-field images of doubly labeled neurons for Tlr4 (red) and Calca (blue) in the ganglionic mass of C57BI6/J mice. Overall, these data indicate that TIr4 and Calca were frequently co-expressed in the same neurons. The numbers are meant to indicate four examples of profiles co-expressing Calca and TIr4 mRNAs. Ganglia were counterstained with hematoxylin. E, Quantification of Tlr4 signals (dots) in cell profiles negative (left) or positive (right) for Calca. Individual cell profiles are displayed as black circles. A total of 923 cell counterstained profiles were counted, $n=4$ mice. Using ImageJ, the circumference of each profile was determined and further used to categorize cell profiles into small or large/medium cells. Absolute numbers of tlr4-positive profiles is also indicated above each graph. Scale bar in $\boldsymbol{C}$ applies to $\boldsymbol{D}$. cNG, caudal nodose ganglion; rNG, rostral nodose ganglion; JG, jugular ganglion; $X$, vagus nerve trunk.

reported identical degrees of LPS-induced anorexia in animals with capsaicin-mediated or surgery-mediated deafferentation (Schwartz et al., 1997; Porter et al., 1998b; Wieczorek et al., 2005). To our knowledge, prior in vivo studies have rarely examined LPS-induced anorexia before the 1-h postinjection time point (Kent et al., 1992; Liu et al., 2016). However, our data reinforced the view that anorexia is initiated rapidly after intraperitoneal LPS exposure. This observation led us to hypothesize that first, LPS may directly act on vagal afferents to suppress feeding; and second, that prior studies may have missed the early anorectic response to LPS. Contrary to expectation, our 


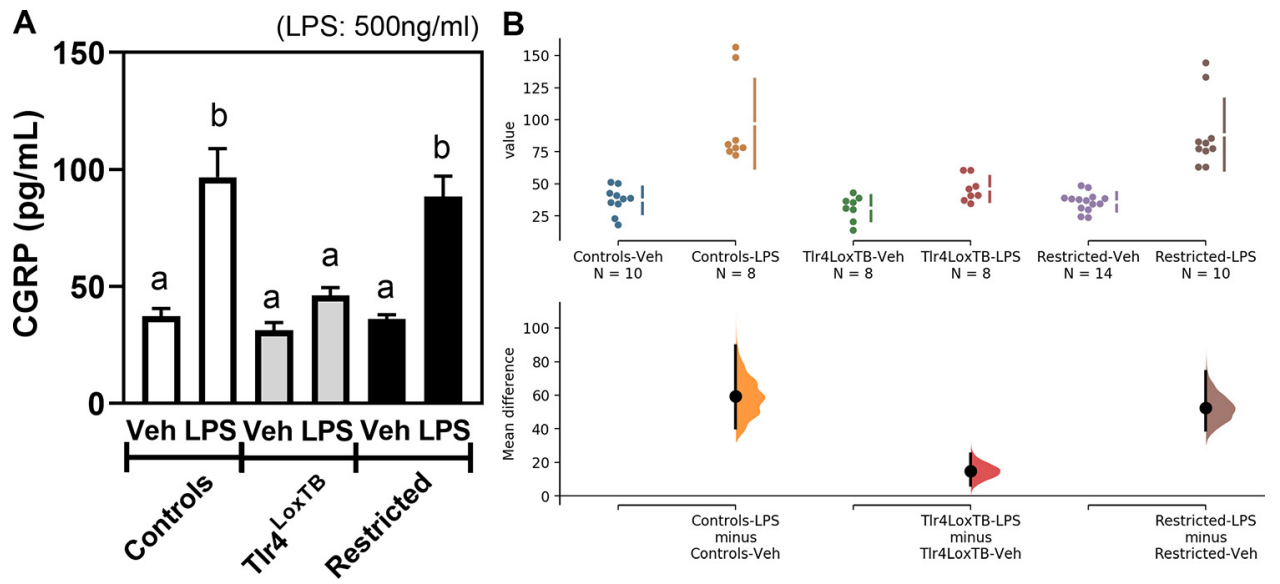

Figure 7. A, LPS-induced CGRP production from Tlr4-expressing vagal afferents. CGRP ELISA from nodose-jugular ganglia organotypic cultures isolated from WT (controls), TIr4LoxTB (KO), and TIr4 ${ }^{\text {LoxTB }} \mathrm{X} \mathrm{Na}_{\mathrm{v}} 1.8-\mathrm{Cre}$ (restricted) animals and treated with LPS $(500 \mathrm{ng} / \mathrm{ml})$ or vehicle (sterile saline). Groups consists of ganglia from $n=5-7$ animals. Data were analyzed using one-way ANOVA followed by Tukey's post hoc test. Different letters indicate significant differences between columns. Data are all expressed as the mean values \pm SEM. B, Estimation statistics we included as the mean difference for three comparisons are shown in the Cumming estimation plot. The raw data are plotted on the upper axes; each mean difference is plotted on the lower axes as a bootstrap sampling distribution. Mean differences are depicted as dots; 95\% confidence intervals are indicated by the ends of the vertical error bars. In Extended Data Figure 7-1, we further assessed the expression levels for Tlr4 and Calca in dorsal root ganglia cultured for $5 \mathrm{~d}$.

findings indicate that TLR4 signaling in peripheral afferents alone is not sufficient to initiate anorexia. As explained below, we believe these findings can be explained by the fact that TLR4 signaling occurs mostly in rostral nodose and jugular vagal afferents supplying the airways, rather than those involved in feeding. Instead, it is likely that LPS-induced anorexia is initiated by the de novo production of cytokines and prostaglandins within the brain (Yao et al., 1999; Layé et al., 2000; Sachot et al., 2004; Chakravarty and Herkenham, 2005; Ching et al., 2007; Elander et al., 2007; Rummel et al., 2008; Skelly et al., 2013). A recent single-cell sequencing study determined that the molecular make-up of jugular afferents is reminiscent of that of spinal nociceptors rather than vagal afferents of the nodose ganglion (Kupari et al., 2019). Thus, the difference of expression of TIr4 mRNA in the nodose versus jugular ganglion is not completely surprising. Considering that the jugular and nodose ganglia are fused in rodents, one prior report of TIr4 expression in the whole nodose ganglion may have been because of a jugular contamination (Hosoi et al., 2005).

\section{TLR4 signaling and vagal CGRP}

In the CNS, TLR4 is enriched in non-neuronal cells, most notably including microglial cells (Lacroix et al., 1998; Laflamme and Rivest, 2001; Lehnardt et al., 2002; Olson and Miller, 2004; Chakravarty and Herkenham, 2005; Kigerl et al., 2007; Madore et al., 2013; Larochelle et al., 2015). Several laboratories also reported TLR4 expression in neurons (Rolls et al., 2007; Yoo et al., 2011; Leow-Dyke et al., 2012; Calvo-Rodríguez et al., 2017). However, the latter studies relied on in vitro data and/or unvalidated antibodies against TLR4. In contrast, high resolution ISH mapping studies have established that TLR4 expression was restricted to non-neuronal cells in normal, inflamed, and injured CNS (Laflamme and Rivest, 2001;
Chakravarty and Herkenham, 2005; Kigerl et al., 2007). Hence, a general agreement is that CNS neurons do not express TLR4, or they do at very low levels. In contrast, TLR4 expression was found to be relatively high in a small subset of vagal afferents. Notably, we found that LPS did not significantly increase $\mathrm{Nf}_{\kappa}$ bia expression in TIr4-expressing $\mathrm{Na}_{\mathrm{v}} 1.8$ neurons. This result is in agreement with the fact that LPS is a poor inducer of the NF- $\kappa$ B pathway in neurons compared with other cell types (Quan et al., 1997; Stern et al., 2000; Laflamme and Rivest, 2001; Chakravarty and Herkenham, 2005; Kigerl et al., 2007; Listwak et al., 2013). In addition, $\mathrm{NF}_{\kappa} \mathrm{B}$-independent signaling mechanisms may account for LPS actions on sensory neurons (Li et al., 2014; Meseguer et al., 2014; Allette et al., 2017; Boonen et al., 2018). This putative non-genomic effect of TLR4 on peripheral afferents differs from its canonical $\mathrm{NF} \kappa \mathrm{B}$-dependent actions on immune, endocrine, and glial cells. Thus, additional studies are warranted in our $\mathrm{Na}_{\mathrm{v}} 1.8$-restricted TLR4 mice to elucidate LPS sensing mechanisms in vagal afferents. Considering the large amount of LPS that is constitutively contained within the gut lumen (Hersoug et al., 2016), we anticipated that TLR4 would be expressed by vagal afferents supplying the intestines. Based on our data, we cannot rule out entirely that certain vagal afferents innervating the gut expressed TLR4. In fact, a small subset of CGRP-positive vagal afferents was reported to supply the rodent stomach (Bai et al., 2019). Nonetheless, it must be stressed that TIr4 mRNA was rarely seen in neurons of the caudal nodose ganglion, where reside vagal afferents innervating the gut. Thus, the common proposition that LPS signaling in vagal afferents sense gut microbial communities is not supported by our findings. Instead, we found abundant expression of TLR4 in CGRP-producing vagal afferents, a subgroup of vagal afferents supplying the upper airways, meninges, and facial skin (Mazzone and Undem, 2016). Moreover, our in vitro data indicate that TLR4 signaling is 
required and sufficient to mediate LPS-induced CGRP release. Interestingly, bacterial infections in the respiratory tract are common and can lead to sepsis more often than in any other primary sites of infection. CGRP is a wellknown immuno-modulatory peptide released from vagal and spinal C-fiber endings (Myers et al., 1996; Abbadie et al., 2002; Abrahamsen et al., 2008; Chiu et al., 2013). Vagal afferents play a key role in airways defenses and coughing (Prescott et al., 2020; Ruhl et al., 2020). Therefore, it is tempting to speculate that the stimulation of TLR4 in vagal airway afferents plays an important immuno-modulatory role in the airways and lungs. For instance, a recent study demonstrated that the release of CGRP from respiratory vagal afferents is critical to bacterial clearance in lungs (Baral et al., 2018). Therefore, further studies in TLR4 reactivated mice are warranted to verify their susceptibility to respiratory infections. Our prediction is that the stimulation of TLR4-bearing vagal (and/ or spinal) neurons supplying the airways during a Gramnegative bacterial infection would trigger an efferent response, probably involving the release of CGRP, aimed at containing inflammation and favoring bacterial clearance. It is without saying that molecules other than TLR4 may also be involved in mediating CGRP release during a bacterial infection, as suggested by several studies (Diogenes et al., 2011; Meseguer et al., 2014; Boonen et al., 2018). In particular, Meseguer and colleagues showed that the release of CGRP from isolated tracheas is a TRPA1-dependent phenomenon. However, based on data obtained with a Trpa1 global knock-out, it cannot be certain that neuronal TRPA1 was involved in the observed effects. Indeed, CGRP is also released from immune cells (BaliuPiqué et al., 2014) and TRPA1 itself has been reported in immune and epithelial cells (Khalil et al., 2018). Moreover, the high dose of LPS used in this prior TRPA1-related study is believed to cause TLR4-independent effects because of LPS interacting with the membrane itself (Redeker and Briscoe, 2019; Yin et al., 2020). Using a lower dose of LPS, other authors have shown TRPA1 to be dispensable for LPS calcium imaging response in sensory neurons (Diogenes et al., 2011; Boonen et al., 2018). Once again, the advantage of our model is that we manipulated TLR4 only in $\mathrm{Na}_{v} 1.8$ neurons of the nodose ganglion. In other words, it is likely that TLR4 and TRP channels are synergistically involved in the release of CGRP from neuronal endings, but TRP channels do not mediate this response alone. Lastly, it must be noted that the transcriptional profile of jugular vagal afferents resembles that of spinal and trigeminal nociceptors (Kupari et al., 2019). It is therefore likely that our findings may be extrapolated to other Tlr4-expressing peripheral nerves including spinal and trigeminal CGRP-positive afferents.

\section{References}

Abbadie C, Lombard MC, Besson JM, Trafton JA, Basbaum Al (2002) Mu and delta opioid receptor-like immunoreactivity in the cervical spinal cord of the rat after dorsal rhizotomy or neonatal capsaicin: an analysis of pre- and postsynaptic receptor distributions. Brain Res 930:150-162.

Abrahamsen B, Zhao J, Asante CO, Cendan CM, Marsh S, MartinezBarbera JP, Nassar MA, Dickenson AH, Wood JN (2008) The cell and molecular basis of mechanical, cold, and inflammatory pain. Science 321:702-705.

Allette YM, Kim Y, Randolph AL, Smith JA, Ripsch MS, White FA (2017) Decoy peptide targeted to Toll-IL-1R domain inhibits LPS and TLR4-active metabolite morphine-3 glucuronide sensitization of sensory neurons. Sci Rep 7:3741.

Alpizar YA, Boonen B, Sanchez A, Jung C, López-Requena A, Naert R, Steelant B, Luyts K, Plata C, De Vooght V, Vanoirbeek JAJ, Meseguer VM, Voets T, Alvarez JL, Hellings PW, Hoet PHM, Nemery B, Valverde MA, Talavera K (2017) TRPV4 activation triggers protective responses to bacterial lipopolysaccharides in airway epithelial cells. Nat Commun 8:1059.

Bai L, Mesgarzadeh S, Ramesh KS, Huey EL, Liu Y, Gray LA, Aitken TJ, Chen Y, Beutler LR, Ahn JS, Madisen L, Zeng H, Krasnow MA, Knight ZA (2019) Genetic identification of vagal sensory neurons that control feeding. Cell 179:1129-1143.e3.

Baliu-Piqué M, Jusek G, Holzmann B (2014) Neuroimmunological communication via CGRP promotes the development of a regulatory phenotype in TLR4-stimulated macrophages. Eur J Immunol 44:3708-3716.

Banks WA, Robinson SM (2010) Minimal penetration of lipopolysaccharide across the murine blood-brain barrier. Brain Behav Immun 24:102-109.

Baral P, Umans BD, Li L, Wallrapp A, Bist M, Kirschbaum T, Wei Y, Zhou Y, Kuchroo VK, Burkett PR, Yipp BG, Liberles SD, Chiu IM (2018) Author correction: nociceptor sensory neurons suppress neutrophil and gammadelta $T$ cell responses in bacterial lung infections and lethal pneumonia. Nat Med 24:417-426.

Berglund ED, Vianna CR, Donato J Jr, Kim MH, Chuang JC, Lee CE, Lauzon DA, Lin P, Brule LJ, Scott MM, Coppari R, Elmquist JK (2012) Direct leptin action on POMC neurons regulates glucose homeostasis and hepatic insulin sensitivity in mice. J Clin Invest 122:1000-1009.

Bluthé RM, Walter V, Parnet P, Layé S, Lestage J, Verrier D, Poole S, Stenning BE, Kelley KW, Dantzer R (1994) Lipopolysaccharide induces sickness behaviour in rats by a vagal mediated mechanism. C R Acad Sci III 317:499-503.

Boonen B, Alpizar YA, Sanchez A, López-Requena A, Voets T, Talavera K (2018) Differential effects of lipopolysaccharide on mouse sensory TRP channels. Cell calcium 73:72-81.

Bret-Dibat JL, Dantzer R (2000) Cholecystokinin receptors do not mediate the suppression of food-motivated behavior by lipopolysaccharide and interleukin-1 beta in mice. Physiol Behav 69:325331.

Bret-Dibat JL, Bluthé RM, Kent S, Kelley KW, Dantzer R (1995) Lipopolysaccharide and interleukin-1 depress food-motivated behavior in mice by a vagal-mediated mechanism. Brain Behav Immun 9:242-246.

Bret-Dibat JL, Creminon C, Couraud JY, Kelley KW, Dantzer R, Kent S (1997) Systemic capsaicin pretreatment fails to block the decrease in food-motivated behavior induced by lipopolysaccharide and interleukin-1beta. Brain Res Bull 42:443-449.

Calvo-Rodríguez M, de la Fuente C, García-Durillo M, GarcíaRodríguez C, Villalobos C, Núñez L (2017) Aging and amyloid beta oligomers enhance TLR4 expression, LPS-induced $\mathrm{Ca}(2+)$ responses, and neuron cell death in cultured rat hippocampal neurons. J Neuroinflammation 14:24.

Chakravarty S, Herkenham M (2005) Toll-like receptor 4 on nonhematopoietic cells sustains CNS inflammation during endotoxemia, independent of systemic cytokines. J Neurosci 25:1788-1796.

Ching S, Zhang H, Belevych N, He L, Lai W, Pu XA, Jaeger LB, Chen Q, Quan N (2007) Endothelial-specific knockdown of interleukin-1 (IL-1) type 1 receptor differentially alters CNS responses to IL-1 depending on its route of administration. J Neurosci 27:1047610486.

Chiu IM, Heesters BA, Ghasemlou N, Von Hehn CA, Zhao F, Tran J, Wainger B, Strominger A, Muralidharan S, Horswill AR, Bubeck Wardenburg J, Hwang SW, Carroll MC, Woolf CJ (2013) Bacteria activate sensory neurons that modulate pain and inflammation. Nature 501:52-57. 
Chow JC, Young DW, Golenbock DT, Christ WJ, Gusovsky F (1999) Toll-like receptor-4 mediates lipopolysaccharide-induced signal transduction. J Biol Chem 274:10689-10692.

Clatworthy AL, Grose E (1999) Immune-mediated alterations in nociceptive sensory function in Aplysia californica. J Exp Biol 202:623630.

Daniel JA, Whitlock BK, Marks DL, Gard JA, Sartin JL (2016) Leukemia inhibitory factor as a mediator of lipopolysaccharide effects on appetite and selected hormones and metabolites. J Anim Sci 94:2789-2797.

de Lartigue G, Barbier de la Serre C, Espero E, Lee J, Raybould HE (2011) Diet-induced obesity leads to the development of leptin resistance in vagal afferent neurons. Am J Physiol Endocrinol Metab 301:E187-E195.

Diogenes A, Ferraz CC, Akopian AN, Henry MA, Hargreaves KM (2011) LPS sensitizes TRPV1 via activation of TLR4 in trigeminal sensory neurons. J Dent Res 90:759-764.

Due MR, Piekarz AD, Wilson N, Feldman P, Ripsch MS, Chavez S, Yin H, Khanna R, White FA (2012) Neuroexcitatory effects of morphine-3-glucuronide are dependent on Toll-like receptor 4 signaling. J Neuroinflammation 9:200.

Eijkelkamp N, Heijnen CJ, Willemen HL, Deumens R, Joosten EA, Kleibeuker W, den Hartog IJ, van Velthoven CT, Nijboer C, Nassar MA, Dorn GW 2nd, Wood JN, Kavelaars A (2010) GRK2: a novel cell-specific regulator of severity and duration of inflammatory pain. J Neurosci 30:2138-2149.

Ek M, Kurosawa M, Lundeberg T, Ericsson A (1998) Activation of vagal afferents after intravenous injection of interleukin-1beta: role of endogenous prostaglandins. J Neurosci 18:9471-9479.

Elander L, Engström L, Hallbeck M, Blomqvist A (2007) IL-1beta and LPS induce anorexia by distinct mechanisms differentially dependent on microsomal prostaglandin E synthase-1. Am J Physiol Regul Integr Comp Physiol 292:R258-267.

Essner RA, Smith AG, Jamnik AA, Ryba AR, Trutner ZD, Carter ME (2017) AgRP neurons can increase food intake during conditions of appetite suppression and inhibit anorexigenic parabrachial neurons. J Neurosci 37:8678-8687.

Feldman-Goriachnik R, Belzer V, Hanani M (2015) Systemic inflammation activates satellite glial cells in the mouse nodose ganglion and alters their functions. Glia 63:2121-2132.

Gavini CK, Bookout AL, Bonomo R, Gautron L, Lee S, MansuyAubert V (2018) Liver X receptors protect dorsal root ganglia from obesity-induced endoplasmic reticulum stress and mechanical allodynia. Cell Rep 25:271-277.e4.

Goehler LE, Relton JK, Dripps D, Kiechle R, Tartaglia N, Maier SF, Watkins LR (1997) Vagal paraganglia bind biotinylated interleukin1 receptor antagonist: a possible mechanism for immune-to-brain communication. Brain Res Bull 43:357-364.

Grabinski TM, Kneynsberg A, Manfredsson FP, Kanaan NM (2015) A method for combining RNAscope in situ hybridization with immunohistochemistry in thick free-floating brain sections and primary neuronal cultures. PLoS One 10:e0120120.

Grossberg AJ, Scarlett JM, Zhu X, Bowe DD, Batra AK, Braun TP, Marks DL (2010) Arcuate nucleus proopiomelanocortin neurons mediate the acute anorectic actions of leukemia inhibitory factor via gp130. Endocrinology 151:606-616.

Hansen MK, Daniels S, Goehler LE, Gaykema RP, Maier SF, Watkins LR (2000) Subdiaphragmatic vagotomy does not block intraperitoneal lipopolysaccharide-induced fever. Auton Neurosci 85:83-87.

Helke CJ, Niederer AJ (1990) Studies on the coexistence of substance $\mathrm{P}$ with other putative transmitters in the nodose and petrosal ganglia. Synapse 5:144-151.

Helley MP, Abate W, Jackson SK, Bennett JH, Thompson SW (2015) The expression of Toll-like receptor 4, 7 and co-receptors in neurochemical sub-populations of rat trigeminal ganglion sensory neurons. Neuroscience 310:686-698.

Hersoug LG, Møller P, Loft S (2016) Gut microbiota-derived lipopolysaccharide uptake and trafficking to adipose tissue: implications for inflammation and obesity. Obes Rev 17:297-312.
Ho J, Tumkaya T, Aryal S, Choi H, Claridge-Chang A (2019) Moving beyond $P$ values: data analysis with estimation graphics. Nat Methods 16:565-566.

Hoshino K, Takeuchi O, Kawai T, Sanjo H, Ogawa T, Takeda Y, Takeda K, Akira S (1999) Cutting edge: toll-like receptor 4 (TLR4)deficient mice are hyporesponsive to lipopolysaccharide: evidence for TLR4 as the Lps gene product. J Immunol 162:3749-3752.

Hosoi T, Okuma Y, Matsuda T, Nomura Y (2005) Novel pathway for LPS-induced afferent vagus nerve activation: possible role of nodose ganglion. Auton Neurosci 120:104-107.

Hua XY, Chen P, Fox A, Myers RR (1996) Involvement of cytokines in lipopolysaccharide-induced facilitation of CGRP release from capsaicin-sensitive nerves in the trachea: studies with interleukin1 beta and tumor necrosis factor-alpha. J Neurosci 16:4742-4748.

Huang HY, Lai YL (2003) Lipopolysaccharide induces preprotachykinin gene expression. Am J Respir Cell Mol Biol 29:606-612.

Kent S, Kelley KW, Dantzer R (1992) Effects of lipopolysaccharide on food-motivated behavior in the rat are not blocked by an interleukin-1 receptor antagonist. Neurosci Lett 145:83-86.

Khalil M, Alliger K, Weidinger C, Yerinde C, Wirtz S, Becker C, Engel MA (2018) Functional Role of Transient Receptor Potential Channels in Immune Cells and Epithelia. Front Immunol 9:174.

Kigerl KA, Lai W, Rivest S, Hart RP, Satoskar AR, Popovich PG (2007) Toll-like receptor (TLR)-2 and TLR-4 regulate inflammation, gliosis, and myelin sparing after spinal cord injury. J Neurochem 102:37-50.

Konsman JP, Luheshi GN, Bluthé RM, Dantzer R (2000) The vagus nerve mediates behavioural depression, but not fever, in response to peripheral immune signals; a functional anatomical analysis. Eur J Neurosci 12:4434-4446.

Kunda PE, Cavicchia JC, Acosta CG (2014) Lipopolysaccharides and trophic factors regulate the LPS receptor complex in nodose and trigeminal neurons. Neuroscience 280:60-72.

Kupari J, Häring M, Agirre E, Castelo-Branco G, Ernfors P (2019) An atlas of vagal sensory neurons and their molecular specialization. Cell Rep 27:2508-2523.e4.

La JH, Gebhart GF (2011) Colitis decreases mechanosensitive K2P channel expression and function in mouse colon sensory neurons. Am J Physiol Gastrointest Liver Physiol 301:G165-G174.

Lacroix S, Feinstein D, Rivest S (1998) The bacterial endotoxin lipopolysaccharide has the ability to target the brain in upregulating its membrane CD14 receptor within specific cellular populations. Brain Pathol 8:625-640.

Laflamme N, Rivest S (2001) Toll-like receptor 4: the missing link of the cerebral innate immune response triggered by circulating gram-negative bacterial cell wall components. FASEB J 15:155163.

Lai NY, Mills K, Chiu IM (2017) Sensory neuron regulation of gastrointestinal inflammation and bacterial host defense. J Intern Med 282:5-23.

Larochelle A, Bellavance MA, Rivest S (2015) Role of adaptor protein MyD88 in TLR-mediated preconditioning and neuroprotection after acute excitotoxicity. Brain Behav Immun 46:221-231.

Lawrence CB, Brough D, Knight EM (2012) Obese mice exhibit an altered behavioural and inflammatory response to lipopolysaccharide. Dis Model Mech 5:649-659.

Layé S, Parnet P, Goujon E, Dantzer R (1994) Peripheral administration of lipopolysaccharide induces the expression of cytokine transcripts in the brain and pituitary of mice. Brain Res Mol Brain Res 27:157-162.

Layé S, Bluthé RM, Kent S, Combe C, Médina C, Parnet P, Kelley K, Dantzer R (1995) Subdiaphragmatic vagotomy blocks induction of IL-1 beta mRNA in mice brain in response to peripheral LPS. Am J Physiol 268:R1327-R1331.

Layé S, Gheusi G, Cremona S, Combe C, Kelley K, Dantzer R, Parnet P (2000) Endogenous brain IL-1 mediates LPS-induced anorexia and hypothalamic cytokine expression. Am J Physiol Regul Integr Comp Physiol 279:R93-98.

Lee EC, Yu D, Martinez de Velasco J, Tessarollo L, Swing DA, Court DL, Jenkins NA, Copeland NG (2001) A highly efficient Escherichia 
coli-based chromosome engineering system adapted for recombinogenic targeting and subcloning of BAC DNA. Genomics 73:56-65.

Lehnardt S, Lachance C, Patrizi S, Lefebvre S, Follett PL, Jensen FE, Rosenberg PA, Volpe JJ, Vartanian T (2002) The toll-like receptor TLR4 is necessary for lipopolysaccharide-induced oligodendrocyte injury in the CNS. J Neurosci 22:2478-2486.

Leow-Dyke S, Allen C, Denes A, Nilsson O, Maysami S, Bowie AG, Rothwell NJ, Pinteaux E (2012) Neuronal Toll-like receptor 4 signaling induces brain endothelial activation and neutrophil transmigration in vitro. J Neuroinflammation 9:230.

Li Y, Zhang H, Zhang H, Kosturakis AK, Jawad AB, Dougherty PM (2014) Toll-like receptor 4 signaling contributes to Paclitaxel-induced peripheral neuropathy. J Pain 15:712-725.

Li Y, Zhang H, Kosturakis AK, Cassidy RM, Zhang H, KennamerChapman RM, Jawad AB, Colomand CM, Harrison DS, Dougherty PM (2015) MAPK signaling downstream to TLR4 contributes to paclitaxel-induced peripheral neuropathy. Brain Behav Immun 49:255-266.

Lin Y, Lee H, Berg AH, Lisanti MP, Shapiro L, Scherer PE (2000) The lipopolysaccharide-activated toll-like receptor (TLR)-4 induces synthesis of the closely related receptor TLR-2 in adipocytes. J Biol Chem 275:24255-24263.

Listwak SJ, Rathore P, Herkenham M (2013) Minimal NF- $\kappa$ B activity in neurons. Neuroscience 250:282-299.

Liu CY, Mueller MH, Grundy D, Kreis ME (2007) Vagal modulation of intestinal afferent sensitivity to systemic LPS in the rat. Am J Physiol Gastrointest Liver Physiol 292:G1213-G1220.

Liu S, Gallo DJ, Green AM, Williams DL, Gong X, Shapiro RA, Gambotto AA, Humphris EL, Vodovotz Y, Billiar TR (2002) Role of toll-like receptors in changes in gene expression and NF-kappa B activation in mouse hepatocytes stimulated with lipopolysaccharide. Infect Immun 70:3433-3442.

Liu Y, Huang Y, Liu T, Wu H, Cui H, Gautron L (2016) Lipopolysacharide rapidly and completely suppresses AgRP neuron-mediated food intake in male mice. Endocrinology 157:23802392.

Madore C, Joffre C, Delpech JC, De Smedt-Peyrusse V, Aubert A, Coste L, Layé S, Nadjar A (2013) Early morphofunctional plasticity of microglia in response to acute lipopolysaccharide. Brain Behav Immun 34:151-158.

Marrone MC, Morabito A, Giustizieri M, Chiurchiù V, Leuti A, Mattioli M, Marinelli S, Riganti L, Lombardi M, Murana E, Totaro A, Piomelli D, Ragozzino D, Oddi S, Maccarrone M, Verderio C, Marinelli S (2017) TRPV1 channels are critical brain inflammation detectors and neuropathic pain biomarkers in mice. Nat Commun 8:15292.

Martin SM, Wilson BC, Chen X, Takahashi Y, Poulin P, Pittman QJ (2000) Vagal CCK and 5-HT(3) receptors are unlikely to mediate LPS or IL-1beta-induced fever. Am J Physiol Regul Integr Comp Physiol 279:R960-R965.

Mazzone SB, Undem BJ (2016) Vagal afferent innervation of the airways in health and disease. Physiol Rev 96:975-1024.

Meseguer V, Alpizar YA, Luis E, Tajada S, Denlinger B, Fajardo O, Manenschijn JA, Fernández-Peña C, Talavera A, Kichko T, Navia B, Sánchez A, Señarís R, Reeh P, Pérez-García MT, López-López JR, Voets T, Belmonte C, Talavera K, Viana F (2014) TRPA1 channels mediate acute neurogenic inflammation and pain produced by bacterial endotoxins. Nat Commun 5:3125.

Miyamoto S, Verma IM (1995) Rel/NF-kappa B/I kappa B story. Adv Cancer Res 66:255-292.

Muta T, Osaki K, Yamano Y (2002) Translocation t(9;22) (p23;q11) in atypical chronic myeloid leukemia (aCML) presenting osteolytic lesions. Int J Hematol 76:344-348.

Myers A, Undem B, Kummer W (1996) Anatomical and electrophysiological comparison of the sensory innervation of bronchial and tracheal parasympathetic ganglion neurons. J Auton Nerv Syst 61:162-168.

Ochoa-Cortes F, Ramos-Lomas T, Miranda-Morales M, Spreadbury I, Ibeakanma C, Barajas-Lopez C, Vanner S (2010) Bacterial cell products signal to mouse colonic nociceptive dorsal root ganglia neurons. Am J Physiol Gastrointest Liver Physiol 299:G723-G732.

Olson JK, Miller SD (2004) Microglia initiate central nervous system innate and adaptive immune responses through multiple TLRs. J Immunol 173:3916-3924.

Park BS, Song DH, Kim HM, Choi BS, Lee H, Lee JO (2009) The structural basis of lipopolysaccharide recognition by the TLR4MD-2 complex. Nature 458:1191-1195.

Poltorak A, He X, Smirnova I, Liu MY, Van Huffel C, Du X, Birdwell D, Alejos E, Silva M, Galanos C, Freudenberg M, Ricciardi-Castagnoli $\mathrm{P}$, Layton B, Beutler B (1998a) Defective LPS signaling in C3H/HeJ and $\mathrm{C} 57 \mathrm{BL} / 10 \mathrm{ScCr}$ mice: mutations in TIr4 gene. Science 282:2085-2088.

Poltorak A, Smirnova I, He X, Liu MY, Van Huffel C, McNally O, Birdwell D, Alejos E, Silva M, Du X, Thompson P, Chan EK, Ledesma J, Roe B, Clifton S, Vogel SN, Beutler B (1998b) Genetic and physical mapping of the Lps locus: identification of the toll-4 receptor as a candidate gene in the critical region. Blood Cells Mol Dis 24:340-355.

Poltorak A, Ricciardi-Castagnoli P, Citterio S, Beutler B (2000) Physical contact between lipopolysaccharide and toll-like receptor 4 revealed by genetic complementation. Proc Natl Acad Sci USA 97:2163-2167.

Porter MH, Arnold M, Langhans W (1998a) TNF-alpha tolerance blocks LPS-induced hypophagia but LPS tolerance fails to prevent TNF-alpha-induced hypophagia. Am J Physiol 274:R741-R745.

Porter MH, Hrupka BJ, Langhans W, Schwartz GJ (1998b) Vagal and splanchnic afferents are not necessary for the anorexia produced by peripheral IL-1beta, LPS, and MDP. Am J Physiol 275:R384R389.

Prescott SL, Umans BD, Williams EK, Brust RD, Liberles SD (2020) An airway protection program revealed by sweeping genetic control of vagal afferents. Cell 181:574-589.e14.

Quan N, Whiteside M, Kim L, Herkenham M (1997) Induction of inhibitory factor kappaBalpha mRNA in the central nervous system after peripheral lipopolysaccharide administration: an in situ hybridization histochemistry study in the rat. Proc Natl Acad Sci USA 94:10985-10990.

Redeker C, Briscoe WH (2019) Interactions between mutant bacterial lipopolysaccharide (LPS-Ra) surface layers: surface vesicles, membrane fusion, and effect of $\mathrm{Ca}(2+)$ and temperature. Langmuir 35:15739-15750.

Riley TP, Neal-McKinney JM, Buelow DR, Konkel ME, Simasko SM (2013) Capsaicin-sensitive vagal afferent neurons contribute to the detection of pathogenic bacterial colonization in the gut. $J$ Neuroimmunol 257:36-45.

Rolls A, Shechter R, London A, Ziv Y, Ronen A, Levy R, Schwartz M (2007) Toll-like receptors modulate adult hippocampal neurogenesis. Nat Cell Biol 9:1081-1088.

Ross G, Hübschle T, Pehl U, Braun HA, Voigt K, Gerstberger R, Roth $J$ (2003) Fever induction by localized subcutaneous inflammation in guinea pigs: the role of cytokines and prostaglandins. J Appl Physiol (1985) 94:1395-1402.

Ruhl CR, Pasko BL, Khan HS, Kindt LM, Stamm CE, Franco LH, Hsia CC, Zhou M, Davis CR, Qin T, Gautron L, Burton MD, Mejia GL, Naik DK, Dussor G, Price TJ, Shiloh MU (2020) Mycobacterium tuberculosis sulfolipid-1 activates nociceptive neurons and induces cough. Cell 181:293-305.e11.

Rummel C, Inoue W, Sachot C, Poole S, Hübschle T, Luheshi GN (2008) Selective contribution of interleukin-6 and leptin to brain inflammatory signals induced by systemic LPS injection in mice. $J$ Comp Neurol 511:373-395.

Sachot C, Poole S, Luheshi GN (2004) Circulating leptin mediates lipopolysaccharide-induced anorexia and fever in rats. J Physiol 561:263-272.

Schwartz GJ, Plata-Salamán CR, Langhans W (1997) Subdiaphragmatic vagal deafferentation fails to block feeding-suppressive effects of LPS and IL-1 beta in rats. Am J Physiol 273:R1193-R1198. 
Sergeev VG, Akmaev IG (2000) Effects of vagotomy and bacterial lipopolysaccharide on food intake and expression of cyclooxygenase-2 mRNA in rat brain vessels. Bull Exp Biol Med 129:553-555.

Skelly DT, Hennessy E, Dansereau MA, Cunningham C (2013) A systematic analysis of the peripheral and CNS effects of systemic LPS, IL- $1 \beta$, [corrected] TNF- $\alpha$ and IL-6 challenges in C57BL/6 mice. PLoS One 8:e69123.

Soldano A, Alpizar YA, Boonen B, Franco L, López-Requena A, Liu G, Mora N, Yaksi E, Voets T, Vennekens R, Hassan BA, Talavera K (2016) Gustatory-mediated avoidance of bacterial lipopolysaccharides via TRPA1 activation in Drosophila. Elife 5:e13133.

Stern EL, Quan N, Proescholdt MG, Herkenham M (2000) Spatiotemporal induction patterns of cytokine and related immune signal molecule mRNAs in response to intrastriatal injection of lipopolysaccharide. J Neuroimmunol 106:114-129.

Stirling LC, Forlani G, Baker MD, Wood JN, Matthews EA, Dickenson AH, Nassar MA (2005) Nociceptor-specific gene deletion using heterozygous NaV1.8-Cre recombinase mice. Pain 113:27-36.

Wang H, Su N, Wang LC, Wu X, Bui S, Nielsen A, Vo HT, Luo Y, Ma XJ (2014) Quantitative ultrasensitive bright-field RNA in situ hybridization with RNAscope. Methods Mol Biol 1211:201-212.

Wang J, Kollarik M, Ru F, Sun H, McNeil B, Dong X, Stephens G, Korolevich S, Brohawn P, Kolbeck R, Undem B (2017) Distinct and common expression of receptors for inflammatory mediators in vagal nodose versus jugular capsaicin-sensitive/TRPV1-positive neurons detected by low input RNA sequencing. PLoS One 12: e0185985.

Wieczorek M, Swiergiel AH, Pournajafi-Nazarloo H, Dunn AJ (2005) Physiological and behavioral responses to interleukin-1beta and LPS in vagotomized mice. Physiol Behav 85:500-511.

Yao JH, Ye SM, Burgess W, Zachary JF, Kelley KW, Johnson RW (1999) Mice deficient in interleukin-1 beta converting enzyme resist anorexia induced by central lipopolysaccharide. Am J Physiol 277: R1435-R1443.

Yin N, Gao Q, Tao W, Chen J, Bi J, Ding F, Wang Z (2020) Paeoniflorin relieves LPS-induced inflammatory pain in mice by inhibiting NLRP3 inflammasome activation via transient receptor potential vanilloid 1. J Leukoc Biol 108:229-241.

Yoo KY, Yoo DY, Hwang IK, Park JH, Lee CH, Choi JH, Kwon SH, Her S, Lee YL, Won MH (2011) Time-course alterations of Toll-like receptor 4 and NF- $\kappa \mathrm{B}$ p65, and their co-expression in the gerbil hippocampal CA1 region after transient cerebral ischemia. Neurochem Res 36:2417-2426.

Yu S, Undem BJ, Kollarik M (2005) Vagal afferent nerves with nociceptive properties in guinea-pig oesophagus. J Physiol 563:831842. 